\title{
Predictive and diagnostic biomarkers for gestational diabetes and its associated metabolic and cardiovascular diseases
}

\author{
A. Lorenzo-Almorós ${ }^{1}$, T. Hang ${ }^{1}$, C. Peiró ${ }^{2}$, L. Soriano-Guillén ${ }^{3}$, J. Egido ${ }^{1,5}$, J. Tuñón ${ }^{4}$ and Ó. Lorenzo ${ }^{1,5 *}$
}

\begin{abstract}
Gestational diabetes mellitus (GDM) is defined as the presence of high blood glucose levels with the onset, or detected for the first time during pregnancy, as a result of increased insulin resistance. GDM may be induced by dysregulation of pancreatic $\beta$-cell function and/or by alteration of secreted gestational hormones and peptides related with glucose homeostasis. It may affect one out of five pregnancies, leading to perinatal morbidity and adverse neonatal outcomes, and high risk of chronic metabolic and cardiovascular injuries in both mother and offspring. Currently, GDM diagnosis is based on evaluation of glucose homeostasis at late stages of pregnancy, but increased age and body-weight, and familiar or previous occurrence of GDM, may conditionate this criteria. In addition, an earlier and more specific detection of GDM with associated metabolic and cardiovascular risk could improve GDM development and outcomes. In this sense, 1st-2nd trimester-released biomarkers found in maternal plasma including adipose tissue-derived factors such as adiponectin, visfatin, omentin-1, fatty acid-binding protein- 4 and retinol binding-protein-4 have shown correlations with GDM development. Moreover, placenta-related factors such as sex hormone-binding globulin, afamin, fetuin-A, fibroblast growth factors-21/23, ficolin-3 and follistatin, or specific microRNAs may participate in GDM progression and be useful for its recognition. Finally, urine-excreted metabolites such as those related with serotonin system, non-polar amino-acids and ketone bodies, may complete a predictive or earlydiagnostic panel of biomarkers for GDM.
\end{abstract}

Keywords: Gestational diabetes, Predictive biomarkers, Diagnostic biomarkers, Metabolic disease, Cardiovascular disease

\section{Background}

During pregnancy, women must adapt her body systems to support nutrient and oxygen supply for the growth of the fetus and subsequent lactation [1]. Inappropriate adaptation of maternal physiology may lead to complications of pregnancy, such as gestational diabetes mellitus (GDM). The American Diabetes Association (ADA) has categorized GDM as an independent type of diabetes, caused and developed by different mechanisms, and requiring specific diagnosis and treatment approaches

\footnotetext{
*Correspondence: olorenzo@fid.es

${ }^{1}$ Renal, Vascular and Diabetes Laboratory, Instituto de Investigaciones Sanitarias-Fundación Jiménez Díaz, Universidad Autónoma de Madrid, Av. Reyes Católicos 2, 28040 Madrid, Spain

Full list of author information is available at the end of the article
}

[2]. GDM may originate from specific gene mutations and/or dysregulation of placental hormones and $\beta$-cell injury, and can be favoured by advanced age, gynaecological alterations and diabesogenic factors. GDM is usually developed after the 2nd trimester of pregnancy, between the 24th and the 28th week of gestation [1,3], and it can trigger serious and long-term consequences for fetal and maternal health, in particular, those on metabolism and cardiovascular physiology [4]. According to the International Association of Diabetes and Pregnancy Study Groups (IADPSG), GDM may complicate $15-20 \%$ pregnancies, and has being augmented in the last 20 years in all ethnic groups as much as $27 \%$ [5]. However, the exact prevalence of GDM remains unknown, possibly due to the different diagnostic criteria. 
The original classification of GDM, dated from 1949, was based on age at onset of GDM and on duration of associated metabolic and cardiovascular complications, ranging from "type A" (more favourable) to "type F" (more deleterious) [6]. Recently, new principles including glucose homeostasis, body weight and family history of GDM, have been considered for clinical practice. Also, a specific distinction has been made between pregestational diabetes and GDM, since the prevalence of diabetes along with overweight and obesity have been increasing worldwide at younger ages [7]. Unfortunately, current criteria for GDM diagnosis, based on glucose homeostasis, cannot anticipate or detect all GDM cases neither distinguish those women under cardiovascular risk [8]. The knowledge of new biomarkers for premature detection of GDM with/without associated cardiovascular risk could advance the appropriated management of these patients. In particular, alteration of those biomarkers would classify GDM subjects to initiate early adjustments of specific detrimental factors and tissue responses, in both mother and fetus.

\section{Maternal adaptations of metabolism and cardiovascular system during pregnancy}

Specific metabolic and cardiovascular changes occur in women to acclimate to the pregnant state. Some modifications appear very early in pregnancy, even before the formation of a functional placenta [9]. The maternal pancreatic $\beta$-cell mass expands due to both hyperplasia and hypertrophy of islets, enhancing insulin secretion [10]. Thus, maternal insulin sensitivity is frequently increased, subsequently with lipogenesis and lipid storage at the adipose tissue. Also, alterations in cardiac size, morphology and function must respond to hormonal and metabolic demands. In this sense, the stimulation of systemic vasodilation, blood perfusion and cardiac output increases blood volume to handle with the oxygen and nutrient request [11]. However, later, by the 2nd-3rd trimester of pregnancy and coinciding with the fast growth of fetus, a decrease in insulin sensitivity and an induction of lipolysis and hepatic gluconeogenesis is observed [12]. Insulin receptors and signaling are also ameliorated, and $\beta$-cells react by producing more insulin to maintain an euglycemic state [13, 14]. Also, heart increases rate, wall thicknesses and contractility, stimulating ventricular compliance [15]. Importantly, evidence in human and mostly in animal models have confirmed a placental control of metabolism and cardiovascular homeostasis.

\section{Placental regulation of metabolism and cardiovascular system}

From the 6th week of pregnancy, placenta releases a variety of molecules with physiological effects on metabolism and cardiovascular system for both mother and fetus [16]. Among placental factors, progesterone and oestrogen are key steroid hormones for controlling insulin sensitivity [17]. Both steroids prompt pancreatic hypertrophy, though progesterone reduces insulin-stimulated glucose uptake and oestrogen stimulates systemic insulin sensitivity. They also exert opposite effects on food intake and vascular physiology. Progesterone stimulates appetite and fat deposition, as well as neuropeptide-Y expression for vasoconstriction, whereas oestrogen promotes leptin-dependent satiety and vasodilatation [18]. Moreover, progesterone decreases cardiomyocyte apoptosis, and triggers metabolic shift from carbohydrate to lipid, as a main energetic substrate for the myocardium [19]. Other placental factors can also modulate metabolic and cardiovascular function during pregnancy. Leptin reduces food intake during gestation [20], and neuroactive hormones as melatonin and serotonin, improve glucose tolerance and insulin sensitivity [21]. Also, oxytocin reduces glucose and insulin intolerance, food intake and adiposity, and lowers blood pressure and cardiac oxidation/inflammation [22]. Furthermore, a fine metabolic and cardiovascular control will depend on release of the prolactin and growth hormone (PRL-GH) family. PRL induces $\beta$-cell proliferation and insulin secretion, while GH promotes the cardiac metabolic shift to lipid and reduces insulin signalling [23]. PRL triggers food intake through leptin inhibition, but GH decreases appetite by attenuation of ghrelin and neuropeptide- $Y$ expression $[24,25]$. Finally, activin-A and relaxin are also discharged to enhance glucose tolerance and vascular function $[26$, 27]. Thus, during pregnancy, maternal adaptations for metabolic and cardiovascular needs should be finely regulated by placental factors. The inappropriate and/or unbalanced delivery or action of these molecules might increase the risk of GDM and associated cardiovascular pathologies [16].

\section{GDM aetiology and associated risk factors}

Given the prevalence of GDM along family members, a genetic predisposition has been suggested [28]. Some of the genetic variants for GDM coincide with those of type-II diabetes (T2DM) [29]. Mutations in insulin, insulin receptor, insulin-like growth factor-2, glucokinase, PRL-GH family, hepatocyte nuclear factor-4A, plasminogen activator inhibitor 1 (PAI-1) and melatonin receptor $1 \mathrm{~B}$, among others, have been recognized $[30,31]$. Moreover, Chinese, Southeast Asian, Middle Eastern or Indian backgrounds were linked with higher prevalence of GDM [32]. However, the aetiology of GDM has been traditionally connected to a dysregulation of placental hormones favouring the discharge or effect of those that interfere with insulin sensitivity [14]. In fact, alteration 
in progesterone and oestrogen delivery was correlated with GDM development [33]. Also, leptin was up-regulated in GDM women [34] and mutant female mice in leptin receptor lead to spontaneous development of GDM during pregnancy [35]. Furthermore, other studies have concluded that GDM may be mainly originated from $\beta$-cell injury. The $\beta$-cell number can decrease $41 \%$ in GDM mothers [36], potentially due to delivery of "toxic" adipokines [37]. In this sense, high levels of IFN- $\gamma$ and TNF- $\alpha$ from $\mathrm{CD}^{+}{ }^{+}$Th 1 cells damaged pancreatic islets by controlling the activation of transcription factors (i.e., FOXD3, FOXM1, HNF4 $\alpha$ ) and related proliferative and survival genes [38]. Also, dietary restriction of tryptophan reduced serotonin synthesis and $\beta$-cell expansion, leading to glucose intolerance and increased GDM risk [39].

In addition to genetic mutations, unbalanced hormone secretion and/or $\beta$-cell injury, some other potential risk factors have been suggested for GDM. In particular, the presence of polycystic ovarian syndrome and a clinical history of previous GDM or previous macrosomia in the new-born [28]. Moreover, the National Institute for Health and Clinical Excellence (NICE) and ADA concluded that increased age, and mainly body weight, correlated with GDM incidence [28]. Pregnant women under 20 years-old did not present GDM, whilst 33.3\% of them showed GDM at 20-29 years-old, and 58.3\% at 30-39 years-old [34]. Importantly, obesity can trigger GDM development. Although body mass index (BMI) is not appropriately descriptive for obesity during pregnancy, this anthropomorphic parameter was linked to GDM occurrence [40]. Adipose tissue and placenta can produce a similar pattern of cytokines, which explains the fact that obese women are at higher risk of GDM [41]. Thus, an excessive body weight is frequently present in GDM women, worsening maternal (and fetal) alterations in metabolism and cardiovascular system [42, 43]. Indeed, maternal obesity and GDM may be associated with a state of chronic, low-grade inflammation by which offspring are programmed to develop adult disorders [44]. In this line, intakes of fat and sweet diets before gestation were also associated with elevated risk of GDM, whereas meals based on fruits, vegetables and fish provoked opposite trends [45]. The low ingestion of polyunsaturated fat [46], ascorbic acid [47] and vitamin D [48] were related to GDM, but addition of fibre to diets reduced its prevalence [49]. Also, overproduction of ketone bodies [i.e., $\alpha$-hydroxybutyrate (AHBA)], typical in obesity, paralleled the impairment of insulin secretion during gestation and GDM [50]. In addition, maternal obesity can promote by itself birth defects in offspring. A recent metanalysis collecting data from 1980 has provided robust evidence of a positive association between maternal BMI and the risk for fetal congenital heart defects [51]. Altogether, predisposition to GDM may be favoured by age and diabesogenic factors, and influenced by previous gynaecological alterations of the subject.

\section{Maternal pathologies associated to GDM development}

A systemic low-grade inflammation is physiologically prompted during pregnancy by humoral immunity in order to maintain a safe environment and to avoid fetal rejection [52]. However, by transcriptomics, Radaelly's laboratory found in placenta a highly expressed proinflammatory pattern mainly of endothelial factors, reflecting chronic inflammation with signs of major vascular dysfunction [53]. Among these factors, receptors for interleukin (IL)-8, IL-1 and leptin, together with pentraxin-related gene (PTX-3) were upregulated. Other authors demonstrated high levels of pro-inflammatory serum high sensitive C-reactive protein (hs-CRP) [54], E-selectin, osteoprotegerin, adhesion molecules (VCAM1, ICAM-1), symmetric dimethylarginine (SDMA) and a disintegrin and metalloproteinase (ADAM) [55]. Similarly, a pro-inflammatory pattern of upregulated adipokines (i.e., IL- 6 and hs-CRP) and diminished antiinflammatory adiponectin was also observed in adipose tissue from GDM women [56]. Remarkably, this proinflammatory milieu, together with the dysregulated secretion of placental factors and/or $\beta$-cell injury, could trigger metabolic and cardiovascular diseases in GDM women and offspring [57].

\section{Metabolic and cardiovascular disorders in GDM women}

The risk of T2DM in women after GDM is elevated in the first 5 years [58], raising up to 50\% risk after 10 years [59], and $70 \%$ after 28 years [60]. Other study established a ten times more likely to develop T2DM within 10 years compared to normal pregnancies [61]. Also, GDM has been related with the development of post-parturition metabolic syndrome, mainly in obese women [62]. Fasting glucose, insulin resistance and $\beta$-cell dysfunction remained after pregnancy [63]. Levels of E-selectin and ICAM-1, fibrinogen, IL-6, tissue inhibitor of metalloproteinase-1 (TIMP-1) and PAI-1 [60, 64, 65], but not adiponectin [66], were prominent in women with previous GDM. Also, subclinical inflammation associated with elevated levels of TIMP-1 were observed in women 4 years after GDM [44]. However, it is not clear whether GDM may be an independent cause of these anomalies or they can be a consequence of related comorbidities such as atherosclerosis, hypertension or obesity [67]. In this sense, the development of postpartum T2DM and metabolic syndrome was independently correlated with endothelial 
dysfunction and increased carotid intima-media thickness in GDM women [65].

On the other hand, maternal cardiovascular adaptations (i.e., increased heart rate, ventricular walls and vasodilatation) return after delivery in normal pregnancies. Cardiac output also decreases within the first hour postpartum and reaches baseline levels after 2 weeks [68]. However, GDM gestations have been linked with subclinical alterations in cardiac structure (i.e., increased thicknesses of left ventricular wall and intraventricular septum) and diastolic dysfunction [69]. Also, it was related to preeclampsia and vasculopathies, specifically, arterial stiffness, endothelial dysfunction and atherosclerosis [44, 70, 71]. More worrying, GDM has been positively linked with a $66 \%$ increase of long-term cardiovascular injuries [72]. An elevated rate of hospitalizations due to cardiovascular failures, and independently of high BMI, was detected in GDM women after parturition [43]. The long-term US CARDIA (Coronary Artery Risk Development in Young Adults) registry demonstrated an increase of left ventricular mass, and abnormalities in left ventricular relaxation and systolic dysfunction in 609 women, 20 years after GDM [73]. Also, left ventricular hypertrophy and diastolic dysfunction remained 8 weeks after delivery [74], and elevation of the triglyceride/HDLlipoprotein ratio was associated with previous GDM in 300 women after 5 years of childbirth [75]. In addition, GDM was associated with a $56 \%$ higher risk of upcoming cardiovascular events, and a 2.3-fold increased risk of cardiovascular incidents in the first decade postpartum, independently of progression to T2DM [76]. Coronary artery disease and stroke were greater in 332 women with previous GDM, independently of T2DM, metabolic syndrome or obesity incidence [77]. Increased rates of myocardial infarction and angina pectoris were observed 7 years after delivery, but, however, were stimulated by obesity, advanced age and hypertension [43].

\section{Fetal and child comorbidities associated with GDM}

Since GDM develops from the 2nd-3rd trimester of pregnancy, GDM pregnancies have not been associated with congenital malformations as pre-gestational diabetes do [78]. However, GDM represents high risk for perinatal morbidity and adverse neonatal outcomes compared to normal pregnancies. The excess of plasma glucose and lipids in GDM mothers was linked to cardiac hypertrophy [79] and dysfunction [80] in fetus. Hyperinsulinemia promoted insulin resistance, which also stimulated cardiac hypertrophy [81]. Also, the increased glucose, amino acids, and fatty acids assimilation observed in GDM placenta, stimulated endogenous fetal production of insulin and insulin-like growth factor-1 (IGF-1), which induced macrosomia [82]. Thus, the risk of stillbirths after GDM is four times higher than in normal pregnancies [83]. Later, neonates from GDM are at increased risk of hypoglycemia due to the high dependence on maternal hyperglycemia. Children and adolescents can reach higher BMI, glucose intolerance and hypertension, independently of macrosomia at birth [84]. Also, they exhibited impairment of diastolic function as a prolonged deceleration time associated with early left ventricular diastolic filling [81]. Furthermore, females are more likely to experience GDM in their own pregnancies, contributing to a vicious intergenerational cycle of this pathology [30].

\section{GDM treatment}

Early intervention for GDM could be crucial to prevent subsequent damage in both mother and fetus [85]. Women with GDM are recommended to initiate a change of lifestyle, as well as pharmaceutical treatment, if needed [86]. For non-obese women with GDM, diets containing 30-35 kcal per kg of body weight, with $33-40 \%$ calories from carbohydrates, are advised [49]. Also, practical exercise before and during pregnancy can preserve glucose homeostasis and improve GDM pathology [87]. In particular, moderate exercise (30 min-5 times/week) has demonstrated attenuation of insulin resistance, GDM and fetal macrosomia in obese and non-obese women [88]. More intense activities ( $>60 \mathrm{~min})$ could, however, provoke hypoglycaemia [89].

Thereafter, if glycemic target is not achieved after 1-2 weeks of lifestyle changes, the American College of Obstetricians and Gynaecologists (ACOG) and NICE guidelines recommend pharmacotherapy [90]. In fact, maternal hyperglycemia and advanced age or BMI by themselves are already indicators of medical requirement [91]. Regarding glucose control, rapid-acting insulin analogues, long-acting insulin or even premixed preparations can be useful for GDM. Unfortunately, hypoglycemia is frequent in some subjects, suggesting the need of alternative administrations, such as those of high doses of intermittent insulin injections. Also, sulfonylureas (i.e., glyburide) may produce similar effects than insulin, but cannot mitigate neonatal hypoglycaemia and macrosomia [92]. Interestingly, metformin reduces hyperglycemia and weight gain more intensively than insulin, though metformin does not decrease neonatal hypoglycaemia or macrosomia [93]. Thus, recent data have suggested a lifestyle modification followed by glyburide or metformin, when fasting glucose is between 95 and $114 \mathrm{mg} / \mathrm{dL}$, or a combination of both drugs, when glucose is $115-125 \mathrm{mg} /$ dL. GDM over $126 \mathrm{mg} / \mathrm{dL}$, should be treated with insulin [94]. New strategies addressing insulin homeostasis as well as adiposity, while protecting cardiovascular system, could be of special interest [95-97]. However, pharmacological treatments might negatively affect either mother 
and offspring with variable degree depending on age and background, pregnancy stage and the presence of comorbidities [98]. An adequate prediction or early diagnosis of GDM by specific, safe and minimally-invasive approaches could reduce short and long-term abnormalities in both mother and offspring.

\section{GDM diagnosis}

Currently, there is not a standardised methodology for GDM identification. Universal or selective screening, different glucose tests and diverse glycemia cut-off values, are being recognized. These criteria also vary among countries and between obstetric and diabetes organizations [8]. Some international (IADPSG [99]) and national (NICE [100]; the German Association for Gynaecology and Obstetrics, DGGG [101]; the Journal of Obstetrics and Gynaecology Canada, JOGC [102]; and the National Institutes of Health, NIH [103]) associations suggest in their guidelines a screening for GDM prediction at the first prenatal visit with gynaecologist (Table 1). After quantifying glucose homeostasis based on different parameters [fasting glucose, random glucose or oral glucose tolerance tests (OGTT) following glucose overload], GDM can be predicted if specific cut-offs are reached, and therapeutic programs are recommended. Otherwise, women will be evaluated again at the third trimester. In contrast, since high levels of glycosylated haemoglobin (HbA1c) unveiled a (modest) correlation with GDM only between the 24th and the 28th week of pregnancy [104], other associations (ACOG [105]; ADA [106]; and the International Federation of Gynaecology and Obstetrics, FIGO [107]) directly advise the screening of GDM at this stage (Table 2). In the one-step strategy, GDM is identified by quantification of glucose homeostasis at the fasting state and after 1-2 h glucose overload. In the twostep routine, GDM is diagnosed when detected hyperglycemia by a glucose challenge test (GCT) is confirmed by another 1-3 h-glucose surplus.

Nevertheless, these criteria based on glucose homeostasis might not anticipate or detect all GDM cases neither distinguish those women under cardiovascular risk [8]. In this sense, alternative biomarkers for assessing glycemic

Table 1 Current criteria for GDM prediction

\begin{tabular}{|c|c|c|c|}
\hline Association & Screening type & Screening approach (first pre-natal visit) & Cut-offs for GDM prediction \\
\hline IADPSG & Universal & Fasting plasma glucose test & Fasting glycemia $\geq 92 \mathrm{mg} / \mathrm{dL}(5.1 \mathrm{mM})$ predict GDM ${ }^{d}$ \\
\hline DGGG & High risk women ${ }^{a}$ & Random plasma glucose test & $\begin{array}{l}\text { Glucose } \geq 200 \mathrm{mg} / \mathrm{dL}(11.1 \mathrm{mM}) \text { proceed with fasting } \\
\text { plasma glucose test } \\
\text { Glucose } 140-199 \mathrm{mg} / \mathrm{dL}(7.8-11.0 \mathrm{mM}) \text { proceed with } \\
\text { fasting plasma glucose test or OGTT }\end{array}$ \\
\hline NICE & Women with previous GDM & $\begin{array}{l}\text { One-step strategy ( } 2 \text { h OGTT for } 75 \text { g glucose } \\
\text { overload) }\end{array}$ & $\begin{array}{l}\text { Fasting glycemia } \geq 100.8 \mathrm{mg} / \mathrm{dL}(5.6 \mathrm{mM}) \\
\text { Glycemia } 2 \mathrm{~h} \text { after overload } \geq 140.4 \mathrm{mg} / \mathrm{dL}(7.8 \mathrm{mM})\end{array}$ \\
\hline $\mathrm{NIH}$ & High risk women ${ }^{b}$ & $\begin{array}{l}\text { Two-steps strategy ( } 1 \text { h GCT for } 50 \text { g glucose over- } \\
\text { load }+3 \text { h } 100 \text { g glucose overload) }\end{array}$ & $\begin{array}{l}\text { Step 1: If glycemia } \geq 130 \mathrm{mg} / \mathrm{dL}(7.2 \mathrm{mM}) \text {, proceed } \\
\text { with } \\
\text { Step } 2^{\mathrm{e}} \text { : } \\
\text { Fasting glycemia } \geq 95 \mathrm{mg} / \mathrm{dL}(5.3 \mathrm{mM}) \\
\text { Glycemia } 1 \mathrm{~h} \text { after overload } \geq 180 \mathrm{mg} / \mathrm{dL}(10.0 \mathrm{mM}) \\
\text { Glycemia } 2 \mathrm{~h} \text { after overload } \geq 155 \mathrm{mg} / \mathrm{dL}(8.6 \mathrm{mM}) \\
\text { Glycemia } 3 \mathrm{~h} \text { after overload } \geq 140 \mathrm{mg} / \mathrm{dL}(7.8 \mathrm{mM})\end{array}$ \\
\hline JOGC & High risk womenc & $\begin{array}{l}\text { Two-steps strategy ( } 1 \text { h GCT for } 50 \text { g glucose over- } \\
\text { load }+2 \text { h OGTT for } 75 \text { g glucose overload) }\end{array}$ & $\begin{array}{l}\text { Step 1: If glycemia } \geq 200 \mathrm{mg} / \mathrm{dL}(11.1 \mathrm{mM}), \mathrm{GDM} \text { is } \\
\text { diagnosed } \\
\text { If glycemia } \geq 140-200 \mathrm{mg} / \mathrm{dL}(7.8-11.1 \mathrm{mM}) \text {, proceed } \\
\text { with } \\
\text { Step 2: } \\
\text { Fasting glycemia } \geq 95 \mathrm{mg} / \mathrm{dL}(5.3 \mathrm{mM}) \\
\text { Glycemia } 1 \mathrm{~h} \text { after overload } \geq 190 \mathrm{mg} / \mathrm{dL}(10.6 \mathrm{mM}) \\
\text { Glycemia } 2 \mathrm{~h} \text { after overload } \geq 162 \mathrm{mg} / \mathrm{dL}(9.0 \mathrm{mM})\end{array}$ \\
\hline
\end{tabular}

After universal or selective screening of pregnant women at the first pre-natal visit, diabetic and obstetrician associations preferentially recommend specific strategies for GDM prediction. Basing on glucose homeostasis, different approaches can be followed. The estimation of GDM is made when any or two (in the $3 \mathrm{~h}$ OGTT) cut-offs are met

OGTT oral glucose tolerance test, GCT glucose challenge test

a Age $\geq 45$ years-old, pre-gestational BMI $\geq 30 \mathrm{~kg} / \mathrm{m}^{2}$, familiar or previous GDM, DM or macrosomia, Asian and Latin American ethnicities, arterial hypertension, dyslipidemia, polycystic ovary syndrome, and history of coronary or cerebral vascular disease

b Similar to DGGG, but including age $\geq 25$ years-old, persistent glucosuria, history of spontaneous abortions and unexplained stillbirths

c Similar to DGGG, but including age $\geq 35$ years-old, and aboriginal and African ethnicities

d If fasting glycemia $\geq 126 \mathrm{mg} / \mathrm{dL}(7.0 \mathrm{mmol} / \mathrm{L})$, DM should be considered

e Following Carpenter/Coustan conversion method 
Table 2 Current criteria for GDM diagnosis

\begin{tabular}{|c|c|c|c|}
\hline Association & Screening type & Screening approach (24th-28th week) & Cut-offs for GDM diagnosis \\
\hline ADA & High risk women ${ }^{\mathrm{a}}$ & \multirow[t]{4}{*}{ One-step strategy (2 h OGTT for 75 g glucose overload) } & \multirow{4}{*}{$\begin{array}{l}\text { Fasting glycemia: } 92-125 \mathrm{mg} / \mathrm{dL}(5.1-6.9 \mathrm{mM})^{\mathrm{b}} \\
\text { Glycemia } 1 \mathrm{~h} \text { after overload } \geq 180 \mathrm{mg} / \mathrm{dL}(10.0 \mathrm{mM}) \\
\text { Glycemia } 2 \text { h after overload: } 153-199 \mathrm{mg} / \mathrm{dL}(8.5-11.0 \mathrm{mM})\end{array}$} \\
\hline IADPSG & Universal & & \\
\hline FIGO & Universal & & \\
\hline DGGG & Universal & & \\
\hline NICE & Universal & One-step strategy (2 h OGTT for 75 g glucose overload) & $\begin{array}{l}\text { Fasting glycemia } \geq 100.8 \mathrm{mg} / \mathrm{dL}(5.6 \mathrm{mM}) \\
\text { Glycemia } 2 \mathrm{~h} \text { after overload } \geq 140.4 \mathrm{mg} / \mathrm{dL}(7.8 \mathrm{mM})\end{array}$ \\
\hline ACOG & Universal & \multirow{2}{*}{$\begin{array}{l}\text { Two-steps strategy (1 h GCT for } 50 \text { g glucose overload } \\
\text { + } 3 \text { h OGTT for } 100 \text { g glucose overload) }\end{array}$} & \multirow{2}{*}{$\begin{array}{l}\text { Step 1: If glycemia } \geq 130 \mathrm{mg} / \mathrm{dL}(7.8 \mathrm{mM}) \text {, proceed with } \\
\text { Step 2d: } \\
\text { Fasting glycemia } \geq 95 \mathrm{mg} / \mathrm{dL}(5.3 \mathrm{mM}) \\
\text { Glycemia } 1 \mathrm{~h} \text { after overload } \geq 180 \mathrm{mg} / \mathrm{dL}(10.0 \mathrm{mM}) \\
\text { Glycemia } 2 \mathrm{~h} \text { after overload } \geq 155 \mathrm{mg} / \mathrm{dL}(8.6 \mathrm{mM}) \\
\text { Glycemia } 3 \mathrm{~h} \text { after overload } \geq 140 \mathrm{mg} / \mathrm{dL}(7.8 \mathrm{mM})\end{array}$} \\
\hline $\mathrm{NIH}$ & Universal & & \\
\hline JOGC & Universal & $\begin{array}{l}\text { Two-steps strategy (1 h GCT for } 50 \mathrm{~g} \text { glucose overload } \\
+2 \text { h OGTT for } 75 \text { g glucose overload) }\end{array}$ & $\begin{array}{l}\text { Step 1: If glycemia } \geq 200 \mathrm{mg} / \mathrm{dL}(11.1 \mathrm{mM}) \text {, GDM is diag- } \\
\text { nosed } \\
\text { If glycemia } \geq 140-200 \mathrm{mg} / \mathrm{dL}(7.8-11.1 \mathrm{mM}) \text {, proceed with } \\
\text { Step 2: } \\
\text { Fasting glycemia } \geq 95 \mathrm{mg} / \mathrm{dL}(5.3 \mathrm{mM}) \\
\text { Glycemia } 1 \mathrm{~h} \text { after overload } \geq 190 \mathrm{mg} / \mathrm{dL}(10.6 \mathrm{mM}) \\
\text { Glycemia } 2 \mathrm{~h} \text { after overload } \geq 162 \mathrm{mg} / \mathrm{dL}(9.0 \mathrm{mM})\end{array}$ \\
\hline
\end{tabular}

After screening of pregnant women at the third trimester, the associations' guidelines preferentially suggest specific approaches for GDM detection. One-step or twosteps schemes can be followed. The diagnosis of GDM is made when any or two (in the $3 \mathrm{~h}$ OGTT) cut-offs are met

a Age $\geq 25$ years-old, BMl $>25 \mathrm{~kg} / \mathrm{m}^{2}$, Asian and Latin American ethnicities, previous history of abnormal glucose tolerance or adverse obstetrics outcomes, and familiar history of DM

b If fasting glycemia $\geq 126 \mathrm{mg} / \mathrm{dL}(7.0 \mathrm{mM}), \mathrm{T} 2 \mathrm{DM}$ should be considered

c If glycemia $2 \mathrm{~h}$ after overload $\geq 200 \mathrm{mg} / \mathrm{dL}$ (11.1 mM), T2DM should be contemplated

d Following Carpenter/Coustan conversion method

control have been proposed in GDM diagnosis. The 1-deoxy form of glucose, known as 1,5-anhydroglucitol, is a naturally occurring dietary polyol. Serum 1,5-anhydroglucitol competes with very high levels of glucose for reabsorption into the kidney, and thus, lower 1,5-anhydroglucitol levels can reflect hyperglycemia and glycosuria [108]. Interestingly, first trimester measurement of 1,5-anhydroglucitol was a valid biomarker for later onset of GDM [109]. In addition, the diagnostic window-period at the third trimester might be late to avoid chronic abnormalities in metabolism and cardiovascular system, in both mother and fetus. Therefore, new specific predictive and diagnostic tools should be evaluated for these patients.

\section{Prospective diagnostic and predictive markers for GDM with associated cardiovascular risk}

During GDM, the dysfunctional adipose tissue and placenta may secrete specific, stable and easy-to-quantify factors, which may participate in inflammation, insulin resistance and cardiovascular injuries. These soluble biomarkers could be found in maternal circulation or urine and might be used for GDM prediction and/or detection, and provide information about the risk of associated metabolic and cardiovascular diseases (Fig. 1). i. Adipose tissue-derived factors

Adipose tissue is an endocrine organ capable of secreting factors (adipokines) with paracrine functions. Some of these molecules could be implicated in promotion and progression of DM and cardiovascular injuries. In particular, leptin is a proinflammatory adipokine involved in immune responses that affects glucose metabolism by antagonizing appetite and insulin action. It also stimulates oxidative stress, arterial stiffness, and atherogenesis [110]. Interestingly, leptin levels have been revealed significantly higher from the 2nd half of pregnancy in normal and overweight women with later GDM diagnosis [111-113] (Table 3A). In contrast, adiponectin, an adipokine with anti-inflammatory, anti-atherosclerotic and insulin-sensitizing proprieties showed constantly lower levels along the 1st-3rd trimester of GDM gestations [113-115]. In fact, hypoadiponectinemia increased by 4.6 times the risk of developing GDM [116], and it was inversely correlated with BMI, insulin resistance and leptin [117]. Thus, the ratio of plasma adiponectin/leptin $(<0.33)$ has been also suggested as predictor of GDM as early as the 6th-14th week of pregnancy [118]. Nevertheless, further investigation analysing the value of the highmolecular weight oligomeric adiponectin could improve these estimations [119]. 


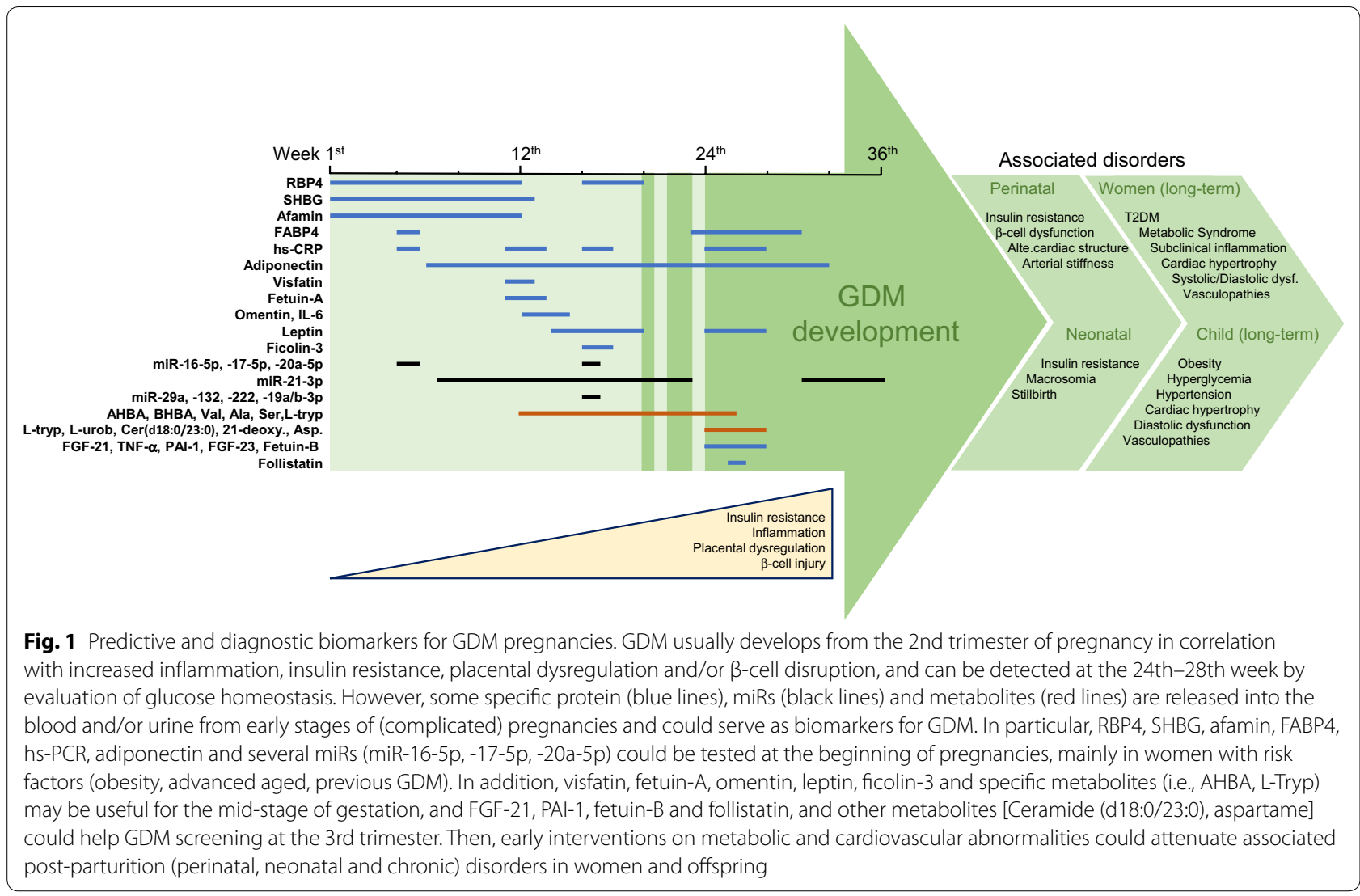

Moreover, proinflammatory adipokines that recruit and activate immune cell subsets in the white adipose tissue, could be quantified. Classical cytokines as hs-CRP and TNF $\alpha$ were higher in the serum from GDM women compared to healthy subjects during the 1st, 2nd and 3rd trimester of pregnancy [120-122] (Tables 3A and 4). PAI-1, a member of the superfamily of serpins that inhibit pro-coagulant plasminogen, was also significantly augmented at the 24-28th week [122], and was considered an early feature of the cardiometabolic biomarker profile of women with recent gestational dysglycemia [123]. Other potential adipokines for GDM diagnosis are visfatin, resistin and omentin. The former is an proinflammatory adipose mediator that promote endothelial dysfunction, atherosclerosis and acute myocardial infarction. It is also increased in patients with T2DM, metabolic syndrome or obesity [124]. Despite of its insulin-like properties by binding to the insulin receptor-1 and promotion of hypoglycaemic effects, visfatin can activate NFkB signalling and chemotaxis, contributing to the development of insulin resistance. Interestingly, visfatin was found increased at the late 1st trimester (Table 3A) [125], but differentially expressed at the 3rd trimester of GDM [126, 127]. Similarly, resistin, another small adipokine hormone related with high levels of
LDL-c and pro-inflammatory molecules, was reduced or unchanged during GDM [128, 129]. However, omentin-1, an adipokine expressed in non-fat cells from adipose tissue (i.e., stromal vascular cells) and involved in vascular tone relaxation by production of endothelial nitric oxide and reduction of both hs-CRP and TNF $\alpha$ signalling [130], was decreased at the 2nd trimester of GDM in parallel to adiponectin, and in contrast to IL-6 [119] (Table 3A).

Other adipose-released factors could be useful for GDM prediction and detection. The fatty acid-binding protein 4 (FABP4) has been correlated with obesity markers, such as high BMI and fat mass, and regulate lipid and glucose metabolism through fatty acid transport and uptake [131]. The retinol-binding protein 4 (RBP4) is a circulating retinol transporter that has been linked with cardiometabolic markers in inflammatory chronic diseases, including obesity, T2DM, metabolic syndrome, and atherosclerosis [132]. Interestingly, high levels of FABP4 were proposed as a predictive biomarker of GDM from at the 1st and 3rd trimester of gestation [133-135]. Also, an upregulation of plasma RBP4 at the 1st and 2nd trimester was modestly correlated with GDM risk, particularly among women with advanced age and obesity $[115,136]$ (Table 3A). Finally, fibroblast growth factor-23 (FGF-23) is as a multi-functional cytokine with relevant 
Table 3 Candidates biomarkers for GDM prediction

\begin{tabular}{|c|c|c|c|c|}
\hline \multicolumn{5}{|l|}{ Panel A } \\
\hline Protein biomarker & Main proposed origin & Week of pregnancy & Change in GDM & Metabolic- and cardiovascular-related properties \\
\hline RBP4 & Liver, adipose, breast & 1st-12th/16-20th & Higher & $\begin{array}{l}\text { Pro-inflammatory Glut4 down-regulation and insulin } \\
\text { resistance } \\
\text { Endothelial dysfunction }\end{array}$ \\
\hline SHBG & Liver, placenta & 1st-13th & Lower & $\begin{array}{l}\text { Polycystic ovary syndrome } \\
\text { Insulin resistance }\end{array}$ \\
\hline Afamin & Liver, placenta & 1st-12th & Higher & $\begin{array}{l}\text { Insulin resistance } \\
\text { Metabolic syndrome }\end{array}$ \\
\hline FABP4 & Adipose, placenta & 4-6th/23rd-30th & Higher & Fatty acid uptake, transport, and metabolism \\
\hline hs-CRP & Liver, pancreas, adipose & $\begin{array}{l}\text { 4-6th/11-14th } \\
16-18 \text { th/24-28th }\end{array}$ & Higher & Pro-inflammatory of acute response \\
\hline Adiponectin & Adipose, breast & 6th-32nd & Lower & $\begin{array}{l}\text { Anti-inflammatory and anti-atherogenesis } \\
\text { Insulin-sensitizer }\end{array}$ \\
\hline Visfatin & Adipose, placenta & 11-13th & Higher & $\begin{array}{l}\text { Pro-inflammatory and chemotactic } \\
\text { Endothelial dysfunction } \\
\text { Acute myocardial infraction }\end{array}$ \\
\hline Fetuin-A & Liver, placenta, fetal tissues & 11-14th & Lower & $\begin{array}{l}\text { Pro-inflammatory } \\
\text { Regulation of the insulin receptor } \\
\text { Vessel calcification }\end{array}$ \\
\hline Omentin-1 & Adipose, placenta & 12-15th & Lower & $\begin{array}{l}\text { Anti-inflammatory } \\
\text { Vasodilatation and endothelial function }\end{array}$ \\
\hline IL-6 & Adipose, lung & 12-15th & Higher & $\begin{array}{l}\text { Pro-inflammatory } \\
\text { Atherogenesis and DM }\end{array}$ \\
\hline Leptin & Adipose, breast & 14-20th/24-28th & Higher & $\begin{array}{l}\text { Reduction on insulin action and appetite Pro-oxidant and } \\
\text { pro-inflammatory } \\
\text { Arterial stiffness }\end{array}$ \\
\hline Ficolin-3 & Liver, placenta & 16th-18th & Lower & $\begin{array}{l}\text { Insulin resistance } \\
\text { T2DM development }\end{array}$ \\
\hline
\end{tabular}

\section{Panel B}

\begin{tabular}{|c|c|c|c|c|}
\hline Genetic biomarker & Main proposed origin & Week of pregnancy & Change in GDM & Metabolic- and cardiovascular-related properties \\
\hline miR-16-5p & Placenta & $4-6$ th/16th & Higher & $\begin{array}{l}\text { Pro-inflammatory } \\
\text { Regulation of vascular endothelial growth }\end{array}$ \\
\hline miR-17-5p & Placenta & $4-6$ th/16th & Higher & $\begin{array}{l}\text { Insulin resistance } \\
\text { Regulation of angiogenesis } \\
\text { Hypertension }\end{array}$ \\
\hline miR-20a-5p & Placenta & $4-6$ th/16th & Higher & $\begin{array}{l}\text { Regulation of } L D L \text { receptor } \\
\text { Modulation of aerobic cardiac capacity } \\
\text { Coronary artery disease }\end{array}$ \\
\hline $\operatorname{miR}-21-3 p$ & Placenta & 7 th-23rd/30-36th & Higher & $\begin{array}{l}\text { Pro-inflammatory } \\
\text { Insulin resistance }\end{array}$ \\
\hline miR-29a & Placenta & 16th & Lower & $\begin{array}{l}\text { Repression of insulin-signaling } \\
\text { Regulation of Glut4 } \\
\text { Control of fatty acid/glucose metabolism }\end{array}$ \\
\hline miR-132 & Placenta & 16th & Lower & $\begin{array}{l}\text { Insulin secretion } \\
\text { Enhancement of glucose homeostasis }\end{array}$ \\
\hline miR-222 & Placenta & 16th & Lower & $\begin{array}{l}\text { Insulin resistance } \\
\text { Downregulation of Glut4 } \\
\text { Hypercholesterolemia }\end{array}$ \\
\hline miR-19a/b-3p & Placenta & 16th & Higher & $\begin{array}{l}\text { Pro-inflammatory } \\
\text { Insulin resistance } \\
\text { Vascular injury }\end{array}$ \\
\hline
\end{tabular}

Some protein (A) and miRs (B) from diverse origins can be early detected in maternal plasma during gestation. Their modified levels have been correlated with later GDM development. Some of them can also provide information about potential metabolic and cardiovascular disorders (https://www.genecards.org/) 
Table 4 Prospective biomarkers for GDM diagnosis

\begin{tabular}{|c|c|c|c|c|}
\hline Protein biomarker & Main proposed origin & Week of pregnancy & Change in GDM & $\begin{array}{l}\text { Metabolic- and cardiovascular-related } \\
\text { properties }\end{array}$ \\
\hline FGF-23 & Adipose, liver & 24-28th & Higher & $\begin{array}{l}\text { Arterial stiffness } \\
\text { Left ventricular hypertrophy }\end{array}$ \\
\hline FGF-21 & Liver, placenta & 24-28th & Higher & $\begin{array}{l}\text { Reduction of diabetes-associated vascular injury } \\
\text { Stimulation of glucose uptake } \\
\text { Arterial fibrosis }\end{array}$ \\
\hline TNFa & Macrophages (adipose, placenta) & 24-28th & Higher & $\begin{array}{l}\text { Pro-inflammatory } \\
\text { Insulin resistance } \\
\text { Glut4 downregulation }\end{array}$ \\
\hline PAl-1 & Artery, placenta, adipose & 24-28th & Higher & $\begin{array}{l}\text { Inhibition of plasminogen } \\
\text { Migration of vascular cells }\end{array}$ \\
\hline Fetuin-B & Liver, placenta, fetal tissues & 24-28th & Higher & $\begin{array}{l}\text { Modulation of the insulin receptor } \\
\text { Systemic inflammation }\end{array}$ \\
\hline Follistatin & Gonadal, intestine, placenta & 26th & Lower & $\begin{array}{l}\text { Antagonism of activin-A } \\
\text { Reduction of cardiac ischaemia-reperfusion injury }\end{array}$ \\
\hline
\end{tabular}

Several proteins released at the 24th-28th week of pregnancy in maternal plasma could be useful to diagnose GDM. Some of them have been related with metabolic and cardiovascular pathologies (https://www.genecards.org/)

implications in phosphate and vitamin-D metabolism. It also participates in cardiovascular disturbances, including atherosclerosis and left ventricular hypertrophy [137, 138]. Notably, FGF-23 estimated adverse cardiovascular outcomes in women with T2DM [139], and also, high levels of FGF-23 (and low of adiponectin) diagnosed GDM at the 3rd trimester [140] (Table 4).

\section{ii. Placenta-secreted factors}

During GDM, some of the previous adipose-derived factors such as TNF $\alpha$, visfatin, omentin and FABP4 can be also expressed and discharged from placenta, contributing to their elevated plasma levels [141]. Moreover, placenta can co-secrete other factors with potential roles in GDM pathogenesis [142]. Liver-derived sex hormone binding globulin (SHBG) is expressed in placenta as a regulator of sex steroid hormones. SHBG has been inversely linked with obesity, insulin resistance, metabolic syndrome, and T2DM [143]. Remarkably, low plasma SHBG levels in the 1st trimester of gestation was a truly biomarker for GDM [120, 144, 145] (Table 3A). Nanda et al. also observed a reduction of SHBG in parallel to adiponectin in GDM women at the 11-13th week of pregnancy, in association with BMI $>30 \mathrm{~kg} / \mathrm{m}^{2}$, previous macrosomia and family history of DM $[145,146]$. In this line, an hepatokine promoter of insulin resistance, fetuin-B, was increased at the 3rd trimester of GDM pregnancies, and returned after delivery [147] (Table 4). More interestingly, at the late 1st trimester, a reduction of plasma fetuin-A levels (and elevated hs-CRP) was also observed [121] (Table 3A). Another member of the FGF family, FGF-21, which induces the browning of white adipose tissue and acts as an upstream effector of adiponectin, was also expressed in placenta and increased in GDM women at the 24th week of gestation [148]. Also, afamin, a glycoprotein member of the albumin family expressed in liver and other peripheral tissues (i.e., placenta), may serve as an early (1st trimester) biomarker for pathological glucose and lipid metabolism during pregnancy [149]. In this regard, the decreased levels of ficolin-3 (an activator of the lectin pathway of the complement system expressed in liver and placenta) and the increased ratio of ficolin-3/adiponectin were predictive of GDM at the 16-18th week of gestation [115] (Table 3A). Finally, follistatin, a gonadal regulator of follicular-stimulant hormone and activin- $\mathrm{A}$, with angiogenic, anti-inflammatory and cardioprotective properties, were lowered in the 3rd trimester of GDM pregnancy [150] (Table 4).

In addition, non-coding RNAs such as micro-RNAs (miR) can be released from placenta to maternal circulation as early as the 6th week of gestation. They could be involved in placenta development, insulin signalling and cardiovascular homeostasis [151, 152]. More than 600 placental miR are mainly encoded into three genetic cluster [chromosome 19 microRNA cluster (C19MC), C14MC, and miR-371-3 cluster]. These miR can be secreted by passive (associated to argonaute proteins or apoptotic bodies) or active (packaged into shedding vesicles, exosomes or lipoproteins) mechanisms, and regulate trophoblasts proliferation (i.e., mir-376c, miR-141, miR-155, miR-675), apoptosis (i.e., miR-29b, miR-182), migration and invasion (i.e., mir-376c, miR-195, miR21, miR-29b), and angiogenesis (miR-16, miR-29b, miR17/92) [153]. However, placental miR can be unbalanced in complicated pregnancies like GDM. A significant downregulation of miR-29a, miR-132 and miR-222 were observed in plasma at the 16th week of pregnant women 
who developed GDM (Table 3B) [154]. miR-29a has been linked to fatty acid and glucose metabolism, whereas miR-132 was related with incretin-dependent insulin secretion and enhancement of glucose homeostasis, and miR-222 was involved in insulin resistance and proatherogenesis [155-157]. By contrast, other miR involved in insulin secretion and signaling such as miR-16-5p, miR-17-5p, miR-19a/b-3p and miR-20a-5p were upregulated and correlated with GDM from the early 1st-2nd trimester $[158,159]$. These miRs have been linked to inflammation, insulin resistance, vascular function and anti-apoptosis [160-163]. Likewise, during the 7th-23rd week of gestation, elevated plasma levels of miR-21-3p were associated with GDM [164, 165] (Table 3B). Interestingly, this miR was linked with preeclampsia and insulin resistance [166, 167].

iii. Urine biomarkers

Maternal urine may be also suitable as a source of predictive and diagnostic markers for GDM. The urine metabolome profile of GDM women in the 3rd trimester of pregnancy identified 14 metabolites related with the steroid hormone biosynthesis and tryptophan metabolism that were significantly elevated [i.e., L-tryptophan, L-urobilinogen, ceramide (d18:0/23:0), 21-deoxycortisol, cucurbitacin-C, aspartame] [168] (Table 5). The upregulation of these pathways could trigger insulin resistance and may respond to oxidative stress and inflammation during GDM. Furthermore, earlier detection (at 12th-26th week of pregnancy) of augmented AHBA, 3-hydroxybutanoic acid (BHBA), valine and alanine levels were observed in urine (and plasma) from GDM mothers [50] (Table 5). Again, these patients also exhibited higher excretion of serotonin and related metabolites like L-tryptophan.

\section{Limitations and future perspectives}

An important issue before selecting these biomarkers to clinical practice will be the analysis of their nature and capacity of sensitivity, specificity, accuracy and reproducibility for GDM. Unfortunately, the accuracy and reproducibility cannot be properly described in most cases due to the scarce clinical and validation studies, and to the different origin of patients, timing of sampling and quantitative methodologies. Nevertheless, some protein and miR biomarkers were tested for sensitivity and specificity (Table 6). In particular, SHBG, hs-CRP and FGF-21 reached $85-100 \%$ of sensitivity, and miR-16-5p, miR-17-5p and miR-20a-5p attained more than 95\% of specificity. Other biomarkers such as leptin, RBP4 and ficolin-3, which displayed $51-81 \%$ of sensitivity and over $64 \%$ of specificity, improved these parameters when they were related to adiponectin (not shown). Especially, the
Table 5 Potential metabolites as biomarkers for GDM

\begin{tabular}{l|l|l|l|} 
Metabolite biomarker & Source & $\begin{array}{l}\text { Week of } \\
\text { pregnancy }\end{array}$ & $\begin{array}{l}\text { Change in } \\
\text { GDM }\end{array}$ \\
\hline AHBA & Urine/plasma & $12-26$ th & Higher \\
\hline BHBA & Urine/plasma & $12-26$ th & Higher \\
\hline Valine & Urine/plasma & $12-26$ th & Higher \\
\hline Alanine & Urine/plasma & $12-26$ th & Higher \\
\hline Serotonin & Urine/plasma & $12-26$ th & Higher \\
\hline L-Tryptophan & Urine/plasma & $12-28$ th & Higher \\
\hline L-Urobilinogen & Urine & $24-28$ th & Higher \\
\hline Ceramide (d18:0/23:0) & Urine & $24-28$ th & Higher \\
\hline 21-Deoxycortisol & Urine & $24-28$ th & Higher \\
\hline Cucurbitacin-C & Urine & $24-28$ th & Higher \\
\hline Aspartame & Urine & $24-28$ th & Higher \\
\hline L & & & \\
\hline
\end{tabular}

The release of some metabolites at the 12th-28th week of pregnancy to maternal urine or plasma, could be suitable for GDM prediction (in orange) and/ or diagnosis (in grey)

ficolin-3/adiponectin ratio reached $90.9 \%$ and $96.5 \%$ of sensitivity and specificity, respectively, for GDM prediction [115]. The sensitivity could have been limited by the variability and quality of samples and detection method, and specificity could have decreased since most biomarkers point out common diabesogenic processes (i.e., insulin resistance, inflammation). In this regard, FGF-21 [148, $169]$, visfatin $[127,170]$, IL-6 $[119,171]$ and resistin $[128$, 129] displayed variable levels depending on pregnancy phase, and afamin, among others, could serve also as a valid biomarker for other complicated pregnancies, like those with preeclampsia [149]. In this line, GDM patients with cardiovascular risk could be classified by testing biomarkers with key roles on cardiovascular pathophysiology. Altered levels of RBP4, adiponectin, visfatin, fetuin-A, omentin-1, IL-6, FGF-21/23, PAI-1 or several miRs (miR-16-5p, miR-17-5p, miR-20a-5p, miR-222 and miR19a/b-3p) could be suspected for future cardiovascular disorders after GDM (Tables 3A, B and 4). However, no data have evidenced this hypothesis yet. In addition, some biomarkers could show a prognostic role for GDM. The increased concentration of RBP4 in early stages of 
Table 6 Sensitivity and specificity of candidate biomarkers for GDM

\begin{tabular}{|c|c|c|c|c|}
\hline Biomarker & Week of pregnancy & Sensitivity (\%) & Specificity (\%) & References \\
\hline SHGB & 1st-12th & 85.0 & 55.3 & {$[121,145]$} \\
\hline \multirow[t]{2}{*}{ hs-CRP } & $4-6$ th & 89.0 & 55.3 & {$[121]$} \\
\hline & $11-14$ th & 86.2 & 50.8 & [122] \\
\hline FGF-21 & 24-28th & 100.0 & 75.0 & [148] \\
\hline miR-16-5p & 4-6th & 41.6 & 95.8 & [159] \\
\hline miR-17-5p & 4-6th & 21.4 & 95.4 & \\
\hline miR-20a-5p & 4-6th & 17.8 & 95.4 & \\
\hline \multirow[t]{2}{*}{ FABP4 } & $4-6$ th & 81.8 & 71.2 & [133] \\
\hline & 23rd-30th & 87.0 & 89.0 & [135] \\
\hline \multirow[t]{2}{*}{ Adiponectin } & 16-18th & 80.7 & 65.1 & [117] \\
\hline & 24-28th & 83.6 & 56.6 & [113] \\
\hline \multirow[t]{2}{*}{ RBP4 } & 16-18th & 79.4 & 79.1 & [136] \\
\hline & & 63.6 & 75.0 & [117] \\
\hline Leptin & 24-28th & 81.2 & 64.2 & [113] \\
\hline miR-132 & 16th & 66.7 & 63.3 & [154] \\
\hline \multicolumn{5}{|l|}{ miR-29a } \\
\hline \multicolumn{5}{|l|}{ miR-222 } \\
\hline Ficolin-3 & 16-18th & 51.1 & 97.7 & [117] \\
\hline Fetuin-A & 11-14th & 58.6 & 76.2 & [122] \\
\hline miR-21-3p & 30-36th & 52.6 & 89.3 & [165] \\
\hline
\end{tabular}

Some of the predictive or diagnostic biomarkers (protein and miR) for GDM were analysed for sensitivity and specificity unveiling different data. These parameters, together with reproducibility and accuracy in quantification will be crucial to validate biomarkers for clinical practise

GDM, was attenuated after sitagliptin treatment and in correlation with insulin resistance [96].

Finally, protein and metabolite biomarkers would deliver a direct measurement of biological effectors involved in GDM, whereas evaluation of miRs could inform about its regulatory mechanisms. Also, modification of protein and miR levels may provide information about specific responses but not about the complete disease. Metabolites, however, usually represent the endpoint or convergence of molecular cascades and is the closest domain to the phenotype, but they exhibit very low reproducibility in validation tests. Thus, integration of data from different molecules could reinforce the understanding and classification of GDM patients by highlighting common pathways that are dysregulated in subsets of patients.

\section{Conclusion}

Nowadays, there is a lack of consensus tools for GDM prediction and diagnosis, which influences on metabolic and cardiovascular evolution for both mother and offspring. After considering risk factors such as increased age, obesity and familiar GDM, specific biomarkers from different stages of GDM pregnancies could be useful for risk stratification and screening of the disease. A 1st trimester decrease of plasma SHBG and adiponectin, in combination with elevated levels of RBP4, afamin, ficolin-3 and certain miR (miR-16-5p, miR-17-5p and miR-20a-5p) could predict GDM with certain warranties (Fig. 1). Quantification of circulant 1,5-anhydroglucitol may also anticipate the GDM development, and later, at the 3rd trimester, a raise of plasma FGF-21 and FABP4 could help an OGTT for GDM diagnosis. In addition, cardiovascular injuries associated to GDM may be predicted or diagnosed by addition of visfatin, omentin-1, fetuin-A, IL-6, PAI-1 and FGF-21/23 to the GDM panel of biomarkers. More research on urine and plasma metabolites (i.e., AHBA, L-tryp) could also propose valid candidates. Prediction and classification of GDM with/ without cardiovascular risk would provide an avenue for personalised medicines, addressed specifically targets the main players leading to disease recurrence, and resulting in better clinical outcomes and improvements in quality of life.

\footnotetext{
Abbreviations

GDM: gestational diabetes mellitus; BMl: body mass index; OGTT: oral glucose tolerance tests; HbA1c: high levels of glycosylated haemoglobin; GCT: glucose challenge test; PRL-GH: prolactin and growth hormone; PAI-1: plasminogen activator inhibitor 1; AHBA: a-hydroxybutyrate; BHBA: 3-hydroxybutanoic acid; IL: interleukin; PTX-3: pentraxin-related gene; CRP: C-reactive protein; SDMA: symmetric dimethylarginine; ADAM: disintegrin and metalloproteinase; TIMP1: tissue inhibitor of metalloproteinase-1; IGF-1: insulin-like growth factor 1;
} 
FABP4: fatty acid-binding protein 4; RBP4: retinol-binding protein 4; FGF-23: fibroblast growth factor-23; SHBG: sex hormone binding globulin; US CARDIA: US Coronary Artery Risk Development in Young Adults; IADPSG: according to the International Association of Diabetes and Pregnancy Study Groups; ADA: American Diabetes Association; NICE: National Institute for Health and Clinical Excellence; ACOG: American College of Obstetricians and Gynaecologists; DGGG: German Association for Gynaecology and Obstetrics; JOGC: Journal of Obstetrics and Gynaecology Canada; NIH: National Institutes of Health; FIGO: International Federation of Gynaecology and Obstetrics.

\section{Acknowledgements}

Not applicable.

\section{Authors' contributions}

L-AA, HT and LO designed, discussed and wrote the work. TJ, PC, S-GL and EJ provided critical analysis. All authors read and approved the final manuscript.

\section{Funding}

This work was supported by the grant PI17/01495, from the Fondo de Investigación Sanitaria (ISC-III) and Fondo Europeo de Desarrollo Regional (FEDER) (for EJ), and grant SAF2017-84776-R, from Ministerio de Educación y Ciencia (for PC).

\section{Availability of data and materials}

Not applicable.

\section{Ethics approval and consent to participate}

Not applicable.

\section{Consent for publication}

Not applicable.

\section{Competing interests}

The authors declare that they have no competing interests.

\begin{abstract}
Author details
${ }_{1}^{1}$ Renal, Vascular and Diabetes Laboratory, Instituto de Investigaciones Sanitarias-Fundación Jiménez Díaz, Universidad Autónoma de Madrid, Av. Reyes Católicos 2, 28040 Madrid, Spain. ${ }^{2}$ Department of Pharmacology, School of Medicine, Universidad Autónoma de Madrid, Madrid, Spain. ${ }^{3}$ Department of Paediatrics, IIS-Fundación Jiménez Díaz, UAM, Madrid, Spain. ${ }^{4}$ Department of Cardiology, Fundación Jiménez Díaz, Madrid, Spain. ${ }^{5}$ Spanish Biomedical Research Centre in Diabetes and Associated Metabolic Disorders (CIBERDEM) Network, Madrid, Spain.
\end{abstract}

Received: 12 July 2019 Accepted: 21 September 2019

Published online: 30 October 2019

\section{References}

1. Corrigan N, Brazil DP, McAuliffe F. Fetal cardiac effects of maternal hyperglycemia during pregnancy. Birth Defects Res A Clin Mol Teratol. 2009;85:523-30.

2. ADA. Standards of medical care in diabetes-2017. Diabetes Care. 2017;2017(40):1-142.

3. American Diabetes Association. Standards of medical care in diabetes - 2017 abridged for primary care providers. Clin Diabetes. 2017;35:5-26.

4. Pedersen J. Diabetes and pregnancy; blood sugar of newborn infants during fasting and glucose administration. Ugeskr Laeger. 1952;114(21):68

5. Ferrara A. Increasing prevalence of gestational diabetes mellitus: a public health perspective. Diabetes Care. 2007;30:S141-6.

6. White P. Pregnancy complicating diabetes. Am J Med. 1949;7(5):609-16

7. Nolan CJ, Damm PPM. Type 2 diabetes across generations: from pathophysiology to prevention and management. Lancet. 2011;378(9786):169-81.

8. Mclntyre HD, Colagiuri S, Roglic G, Hod M. Diagnosis of GDM: a suggested consensus. Best Pract Res Clin Obstet Gynaecol. 2015;29:194-205
9. Drynda R, Peters CJ, Jones PM, Bowe JE. The role of non-placental signals in the adaptation of islets to pregnancy. Horm Metab Res. 2015:47:64-71.

10. Rieck S, Kaestner KH. Expansion of beta-cell mass in response to pregnancy. Trends Endocrinol Metab. 2010;21:151-8.

11. Soma-Pillay P, Nelson-Piercy C, Tolppanen H, Mebazaa A. Physiological changes in pregnancy. Cardiovasc J Afr. 2016:27:89-94.

12. Musial B, Fernandez-Twinn DS, Vaughan OR, Ozanne SE, Voshol P, Sferruzzi-Perri AN, et al. Proximity to delivery alters insulin sensitivity and glucose metabolism in pregnant mice. Diabetes. 2016;65:851-60.

13. Barbour LA, McCurdy CE, Hernandez TL, Kirwan JP, Catalano PMFJE. Cellular mechanisms for insulin resistance in normal pregnancy and gestational diabetes. Diabetes Care. 2012;30(Suppl):2.

14. Richardson AC, Carpenter MW. Inflammatory mediators in gestational diabetes mellitus. Obstet Gynecol Clin North Am. 2007;34:213-24.

15. Cong J, Fan T, Yang X, Squires JW, Cheng G, Zhang L, Zhang Z Structural and functional changes in maternal left ventricle during pregnancy: a three-dimensional speckle-tracking echocardiography study. Cardiovasc Ultrasound. 2015;13:6.

16. Carter AM. Evolution of placental function in mammals: the molecular basis of gas and nutrient transfer, hormone secretion, and immune responses. Physiol Rev. 2012;92:1543-76.

17. Edey LF, Georgiou H, O'Dea KP, Mesiano S, Herbert BR, Lei K, et al. Progesterone, the maternal immune system and the onset of parturition in the mouse. Biol Reprod. 2018:98:376-95.

18. Stelmańska E, Sucajtys-Szulc E. Enhanced food intake by progesterone-treated female rats is related to changes in neuropeptide genes expression in hypothalamus. Endokrynol Pol. 2014;65:46-56.

19. Tiano JP, Mauvais-Jarvis F. Importance of oestrogen receptors to preserve functional $\beta$-cell mass in diabetes. Nat Rev Endocrinol. 2012:8:342-51.

20. Fungfuang W, Terada M, Komatsu N, Moon C, Saito TR. Effects of estrogen on food intake, serum leptin levels and leptin mRNA expression in adipose tissue of female rats. Lab Anim Res. 2013;29:168-73.

21. Owino S, Contreras-Alcantara S, Baba K, Tosini G. Melatonin signaling controls the daily rhythm in blood glucose levels independent of peripheral clocks. PLoS ONE. 2016;11:e0148214.

22. Camerino C. Low sympathetic tone and obese phenotype in oxytocin-deficient mice. Obesity (Silver Spring). 2009;17:980-4.

23. del Rincon J-P, lida K, Gaylinn BD, McCurdy CE, Leitner JW, Barbour $L A$, et al. Growth hormone regulation of p85alpha expression and phosphoinositide 3-kinase activity in adipose tissue: mechanism for growth hormone-mediated insulin resistance. Diabetes. 2007;56:1638-46.

24. Ladyman SR, Augustine RA, Grattan DR. Hormone interactions regulating energy balance during pregnancy. J Neuroendocrinol. 2010;22:805-17.

25. Brown PA, Khan AS, Draghia-Akli R, Pope MA, Bodles-Brakhop AM, Kern DR. Effects of administration of two growth hormone-releasing hormone plasmids to gilts on sow and litter performance for the subsequent three gestations. Am J Vet Res. 2012;73:1428-34.

26. Yong HEJ, Murthi P, Wong MH, Kalionis B, Cartwright JE, Brennecke SP, et al. Effects of normal and high circulating concentrations of activin $A$ on vascular endothelial cell functions and vasoactive factor production. Pregnancy Hypertens. 2015;5:346-53.

27. Mazella J, Tang M, Tseng L. Disparate effects of relaxin and TGFbeta1: relaxin increases, but TGFbeta1 inhibits, the relaxin receptor and the production of IGFBP-1 in human endometrial stromal/decidual cells. Hum Reprod. 2004;19:1513-8.

28. Teh WT, Teede HJ, Paul E, Harrison CL, Wallace EM, Allan C. Risk factors for gestational diabetes mellitus: implications for the application of screening guidelines. Aust N Z J Obstet Gynaecol. 2011;51(1):26-30.

29. Lee KW, Ching SM, Ramachandran V, Yee A, Hoo FK, Chia YC, et al. Prevalence and risk factors of gestational diabetes mellitus in Asia: a systematic review and meta-analysis. BMC Pregnancy Childbirth. 2018;18:494.

30. Lambrinoudaki I, Vlachou SA, Creatsas G. Genetics in gestational diabetes mellitus: association with incidence, severity, pregnancy outcome and response to treatment. Curr Diabetes Rev. 2010;6:393-9.

31. Le TN, Elsea SH, Romero R, Chaiworapongsa T, Francis GL. Prolactin receptor gene polymorphisms are associated with gestational diabetes. Genet Test Mol Biomark. 2013:17:567-71. 
32. Yuen L, Wong VW. Gestational diabetes mellitus: challenges for different ethnic groups. World J Diabetes. 2015;6:1024-32.

33. Qi X, Gong B, Yu J, Shen L, Jin W, Wu Z, et al. Decreased cord blood estradiol levels in related to mothers with gestational diabetes. Medicine (Baltimore). 2017;96:e6962.

34. Ngala RA, Fondjo LA, Gmagna P, Ghartey FN, Awe MA. Placental peptides metabolism and maternal factors as predictors of risk of gestational diabetes in pregnant women. A case-control study. PLoS ONE. 2017;12:e0181613.

35. Yamashita H, Shao J, Ishizuka T, Klepcyk PJ, Muhlenkamp P, Qiao L, et al. Leptin administration prevents spontaneous gestational diabetes in heterozygous Lepr(db/+) mice: effects on placental leptin and fetal growth. Endocrinology. 2001;142:2888-97.

36. Homko C, Sivan E, Chen X, Reece EA, Boden G. Insulin secretion during and after pregnancy in patients with gestational diabetes mellitus. J Clin Endocrinol Metab. 2001;86(2):568-73.

37. Atègbo J-M, Grissa O, Yessoufou A, Hichami A, Dramane KL, Moutairou K, Miled A, Grissa A, Jerbi M, Tabka Z. Modulation of adipokines and cytokines in gestational diabetes and macrosomia. J Clin Endocrinol Metab. 2006:91:4137-43.

38. Moleda P, Fronczyk A, Safranow K, Majkowska L. Adipokines and betacell dysfunction in normoglycemic women with previous gestational diabetes mellitus. Pol Arch Med Wewn. 2015;125:641-8.

39. Kim H, Toyofuku Y, Lynn FC, Chak E, Uchida T, Mizukami H, et al. Serotonin regulates pancreatic beta cell mass during pregnancy. Nat Med. 2010;16:804-8.

40. Robič T, Benedik E, Fidler Mis N, Bratanič B, Rogelj I, Golja P. Challenges in determining body fat in pregnant women. Ann Nutr Metab. 2013;63(4):341-9.

41. Hauguel-de Mouzon S, Guerre-Millo M. The placenta cytokine network and inflammatory signals. Placenta. 2006;27:794-8.

42. Tramontana A, Pablik E, Stangl G, Hartmann B, Dieplinger H, Hafner E. Combination of first trimester serum afamin levels and three-dimensional placental bed vascularization as a possible screening method to detect women at-risk for adverse pregnancy complications like preeclampsia and gestational diabetes mellitus in low-risk pregnancies. Placenta. 2018;62:9-15.

43. McKenzie-Sampson S, Paradis G, Healy-Profitós J, St-Pierre F, Auger N. Gestational diabetes and risk of cardiovascular disease up to 25 years after pregnancy: a retrospective cohort study. Acta Diabetol. 2018. https://doi.org/10.1007/s00592-017-1099-2.

44. Vilmi-Kerälä T, Lauhio A, Tervahartiala T, Palomäki O, Uotila J, Sorsa T, et al. Subclinical inflammation associated with prolonged TIMP-1 upregulation and arterial stiffness after gestational diabetes mellitus: a hospital-based cohort study. Cardiovasc Diabetol. 2017;16:49.

45. Zhang C, Schulze MB, Solomon CG, Hu FB. A prospective study of dietary patterns, meat intake and the risk of gestational diabetes mellitus. Diabetologia. 2006;49(11):2604-13.

46. Wang Y, Storlien LH, Jenkins AB, Tapsell LC, Jin Y, Pan JF, Shao YF, Calvert GD, Moses RG, Shi HL, Zhu XX. Dietary variables and glucose tolerance in pregnancy. Diabetes Care. 2000;23(4):460-4.

47. Zhang C, Williams MA, Sorensen TK, King IB, Kestin MM, Thompson ML, Leisenring WM, Dashow EE, Luthy DA. Maternal plasma ascorbic Acid (vitamin C) and risk of gestational diabetes mellitus. Epidemiology. 2004;15(5):597-604.

48. Zhang C, Qiu C, Hu FB, David RM, Van Dam RM, Bralley A, Williams MA. Maternal plasma 25-hydroxyvitamin D concentrations and the risk for gestational diabetes mellitus. PLoS ONE. 2008;3(11):e37.

49. Poomalar GK. Changing trends in management of gestational diabetes mellitus. World J Diabetes. 2015;6(2):284-95.

50. Leitner M, Fragner L, Danner S, Holeschofsky N, Leitner K, Tischler S, Doerfler H, Bachmann G, Sun X, Jaeger W, Kautzky-Willer A. Combined metabolomic analysis of plasma and urine reveals AHBA, tryptophan and serotonin metabolism as potential risk factors in gestational diabetes mellitus (GDM). Front Mol Biosci. 2017;21(4):84.

51. Zhu Y, Chen Y, Feng Y, Yu D, Mo X. Association between maternal body mass index and congenital heart defects in infants: a meta-analysis. Congenit Heart Dis. 2018;13:271-81.

52. Challis JR, Lockwood CJ, Myatt L, Norman JE. Strauss JF 3rd PF inflammation and pregnancy. Reprod Sci. 2009;16(2):206-15.
53. Radaelli T, Varastehpour A, Catalano P, Hauguel-de Mouzon S. Gestational diabetes induces placental genes for chronic stress and inflammatory pathways. Diabetes. 2003;52(12):2951-8.

54. Rota S, Yildirim B, Kaleli B, Aybek H, Duman K, Kaptanoglu B. C-reactive protein levels in non-obese pregnant women with gestational diabetes. Tohoku J Exp Med. 2005;206(4):341-5.

55. Jensen LA, Chik CL, Ryan EA. Review of gestational diabetes mellitus effects on vascular structure and function. Diabetes Vasc Dis Res. 2016;13(3):170-82.

56. Pantham P, Aye IL, Powell TL. Inflammation in maternal obesity and gestational diabetes mellitus. Placenta. 2015;36(7):709-15.

57. Heitritter SM, Solomon CG, Mitchell GF, Skali-Ounis NSEW. Subclinical inflammation and vascular dysfunction in women with previous gestational diabetes mellitus. J Clin Endocrinol Metab. 2005:90(7):3983-8.

58. Kim C, Newton KM, Knopp RH. Gestational diabetes and the incidence of type 2 diabetes. Diabetes Care. 2002;25:1862-8.

59. Sullivan SD, Umans JG, Ratner R. Gestational diabetes: implications for cardiovascular health. Curr Diabetes Rep. 2012;12(1):43-52.

60. Bellamy L, Casas JP, Hingorani AD, Williams D. Type 2 diabetes mellitus after gestational diabetes: a systematic review and meta-analysis. Lancet. 2009;373(9677):1773-9.

61. Herath $H$, Herath R, Wickremasinghe R. Gestational diabetes mellitus and risk of type 2 diabetes 10 years after the index pregnancy in Sri Lankan women-a community based retrospective cohort study. PLoS ONE. 2017:12:e0179647.

62. Nouhjah S, Shahbazian H, Shahbazian N, Jahanfar S, Jahanshahi A, Cheraghian B, Mohammadi ZD, Ghodrati NH, Houshmandi S. Early postpartum metabolic syndrome in women with or without gestational diabetes: results from Life after gestational diabetes Ahvaz cohort study. Diabetes Metab Syndr. 2017;51871-4021:30427.

63. Xiang AH, Takayanagi M, Black MH, Trigo E, Lawrence JM, Watanabe RM, Buchanan TA. Longitudinal changes in insulin sensitivity and beta cell function between women with and without a history of gestational diabetes mellitus. Diabetologia. 2013;56(12):2753-60.

64. Akinci B, Celtik A, Genc S, Yener S, Demir T, Secil M, et al. Evaluation of postpartum carbohydrate intolerance and cardiovascular risk factors in women with gestational diabetes. Gynecol Endocrinol. 2011;27:361-7.

65. Akinci B, Demir T, Celtik A, Baris M, Yener S, Ozcan MA, et al. Serum osteoprotegerin is associated with carotid intima media thickness in women with previous gestational diabetes. Diabetes Res Clin Pract. 2008;82:172-8.

66. Fakhrzadeh H, Alatab S, Sharifi F, Mirarefein M, Badamchizadeh Z, Ghaderpanahi M, et al. Carotid intima media thickness, brachial flow mediated dilation and previous history of gestational diabetes mellitus. J Obstet Gynaecol Res. 2012;38:1057-63.

67. Gunderson EP, Chiang V, Pletcher MJ, Jacobs DR, Quesenberry CP, Sidney S, Lewis CE. History of gestational diabetes mellitus and future risk of atherosclerosis in mid-life: the coronary artery risk development in young adults study. J Am Heart Assoc. 2014;3(2):e000490.

68. Duvekot JJ, Peeters L. Maternal cardiovascular hemodynamic adaptation to pregnancy. Obstet Gynecol Surv. 1994;49(12 Supp):S1-14.

69. Oliveira AP, Calderon IM, Costa RA, Roscani MG, Magalhães CG, Borges VT. Assessment of structural cardiac abnormalities and diastolic function in women with gestational diabetes mellitus. Diabetes Vasc Dis Res. 2015;12:175-80.

70. Caliskan M, Caklili OT, Caliskan Z, Duran C, Çiftçi FC, Avci E, Güllü H, Kulaksizoglu M, Koca H, Muderrisoglu H. Does gestational diabetes history increase epicardial fat and carotid intima media thickness? Echocardiography. 2014;31(10):1182-7.

71. Karoli R, Siddiqi Z, Fatima J, Shukla V, Mishra PP, Khan FA. Assessment of noninvasive risk markers of subclinical atherosclerosis in premenopausal women with previous history of gestational diabetes mellitus. Heart Views. 2015;16(1):13-8.

72. Retnakaran R, Shah BR. Mild glucose intolerance in pregnancy and risk of cardiovascular disease: a population-based cohort study. CMAJ. 2009;181:371-6.

73. Appiah D, Schreiner PJ, Gunderson EP, Konety SH, Jacobs DR, Nwabuo CC, et al. Association of gestational diabetes mellitus with left ventricular structure and function: the CARDIA study. Diabetes Care. 2016;39:400-7. 
74. Freire CM, Nunes MD, Barbosa MM, de Oliveira Longo JR, Nogueira Al, Diniz SS, Machado LJ, de Oliveira Jr AR. Gestational diabetes: a condition of early diastolic abnormalities in young women. J Am Soc Echocardiogr. 2006;19(10):1251-6.

75. Lekva T, Michelsen AE, Aukrust P, Henriksen T, Bollerslev J, Ueland T. Leptin and adiponectin as predictors of cardiovascular risk after gestational diabetes mellitus. Cardiovasc Diabetol. 2017;16(1):5

76. Kramer CK, Campbell S, Retnakaran R. Gestational diabetes and the risk of cardiovascular disease in women: a systematic review and metaanalysis. Diabetologia. 2019;62(6):905-14.

77. Carr DB, Utzschneider KM, Hull RL, Tong J, Wallace TM, Kodama K, Shofer JB, Heckbert SR, Boyko EJ, Fujimoto WY, Kahn SE. Gestational diabetes mellitus increases the risk of cardiovascular disease in women with a family history of type 2 diabetes. Diabetes Care. 2006;29(9):2078-83.

78. Wahabi HA, Alzeidan RA, Esmaeil SA. Pre-pregnancy care for women with pre-gestational diabetes mellitus: a systematic review and metaanalysis. BMC Public Health. 2012;12:792.

79. Roest PA, van Iperen L, Vis S, Wisse LJ, Poelmann RE, Steegers-Theunissen RP, Molin DG, Eriksson UJ, Gittenberger-De Groot AC. Exposure of neural crest cells to elevated glucose leads to congenital heart defects, an effect that can be prevented by $\mathrm{N}$-acetylcysteine. Birth Defects Res Clin Mol Teratol. 2007;79:231-5.

80. Garg S, Sharma P, Sharma D, Behera V, Durairaj M, Dhall A. Use of fetal echocardiography for characterization of fetal cardiac structure in women with normal pregnancies and gestational diabetes mellitus. J Ultrasound Med. 2014;33:1365-9.

81. Fetita L-S, Sobngwi E, Serradas P, Calvo F, Gautier J-F. Consequences of fetal exposure to maternal diabetes in offspring. J Clin Endocrinol Metab. 2006;91:3718-24.

82. Mitanchez D, Yzydorczyk C, Simeoni U. What neonatal complications should the pediatrician be aware of in case of maternal gestational diabetes? World J Diabetes. 2015;6(5):734.

83. Langer O, Yogev Y, Most O, Xenakis EMJ. Gestational diabetes: the consequences of not treating. Am J Obstet Gynecol. 2005;192:989-97.

84. Tam WH, Ma RCW, Ozaki R, Li AM, Chan MHM, Yuen LY, Lao TTH, Yang X, Ho CS, Tutino GE, Chan JC. In utero exposure to maternal hyperglycemia increases childhood cardiometabolic risk in offspring. Diabetes Care. 2017:40(5):679-86.

85. Sexton H, Heal C, Banks J, Braniff K. Impact of new diagnostic criteria for gestational diabetes. J Obstet Gynaecol Re. 2018;44(3):425-31.

86. ADA. Management of diabetes in pregnancy: standards of medical care in diabetes 2018. Diabetes Care. 2018;41:S137-43.

87. Cordero Y, Mottola MF, Vargas J, Blanco M, Barakat Carballo RO. Exercise is associated with a reduction in gestational diabetes mellitus. Med Sci Sports Exerc. 2015;47(7):1328-33.

88. Artal R, Zavorsky GS, Catanzaro RB. Exercise recommendations in women with gestational diabetes mellitus. Gestational diabetes during and after pregnancy. Springer: London; 2011. p. 243-57.

89. Artal R. The role of exercise in reducing the risks of gestational diabetes mellitus in obese women. Best Pract Res Clin Obst Gynaecol. 2015;29:123-32

90. Walker JD. NICE guidance on diabetes in pregnancy: management of diabetes and its complications from preconception to the postnatal period. NICE clinical guideline 63. London, March 2008. Diabet Med. 2008;25(9):1025-7.

91. Ali A, Shastry S, Nithiyananthan R, Ali A, Ganapathy R. Gestational diabetes-predictors of response to treatment and obstetric outcome. Eur J Obstet Gynecol Reprod Biol. 2018;220:57-60.

92. Balsells M, García-Patterson A, Solà I, Roqué M, Gich I, Corcoy R. Glibenclamide, metformin, and insulin for the treatment of gestational diabetes: a systematic review and meta-analysis. BMJ. 2015;350:h102.

93. Nachum Z, Zafran N, Salim R, Hissin N, Hasanein J, Letova YG, Suleiman A, Yefet E. Glyburide versus metformin and their combination for the treatment of gestational diabetes mellitus: a randomized controlled study. Diabetes Care. 2017;40(3):332-7.

94. Langer O. Pharmacological treatment of gestational diabetes mellitus: point/counterpoint. Am J Obstet Gynecol. 2018;218(5):490-9.

95. Ramírez E, Picatoste B, González-Bris A, Oteo M, Cruz F, Caro-Vadillo A, et al. Sitagliptin improved glucose assimilation in detriment of fattyacid utilization in experimental type-II diabetes: role of GLP-1 isoforms in Glut4 receptor trafficking. Cardiovasc Diabetol. 2018;17:12.
96. Sun X, Zhang Z, Ning H, Sun H, Ji X. Sitagliptin down-regulates retinol-binding protein 4 and reduces insulin resistance in gestational diabetes mellitus: a randomized and double-blind trial. Metab Brain Dis, 2017;32:773-8.

97. Kusaka H, Koibuchi N, Hasegawa Y, Ogawa H, Kim-Mitsuyama S. Empagliflozin lessened cardiac injury and reduced visceral adipocyte hypertrophy in prediabetic rats with metabolic syndrome. Cardiovasc Diabetol. 2016;15(1):157.

98. Alomar MJ. Factors affecting the development of adverse drug reactions (review article). Saudi Pharm J. 2014;22:83-94.

99. International Association of Diabetes and Pregnancy Study Groups Consensus Panel, Metzger BE, Gabbe SG, Persson B, Buchanan TA, Catalano PA, et al. International association of diabetes and pregnancy study groups recommendations on the diagnosis and classification of hyperglycemia in pregnancy. Diabetes Care. 2010;33:676-82.

100. National Collaborating Centre for Women's and Children's Health (UK). Diabetes in pregnancy: management of diabetes and its complications from preconception to the postnatal period. London: National Institute for Health and Care Excellence (UK); 2015.

101. Kleinwechter H, Schäfer-Graf U, Bührer C, Hoesli I, Kainer F, KautzkyWiller A, et al. Gestational diabetes mellitus (GDM) diagnosis, therapy and follow-up care: practice guideline of the German Diabetes Association (DDG) and the German Association for Gynaecologyand Obstetrics (DGGG). Exp Clin Endocrinol Diabetes. 2014;122:395-405.

102. Berger H, Gagnon R, Sermer M, Basso M, Bos H, Brown RN, et al. Diabetes in pregnancy. J Obstet Gynaecol Can. 2016;38:667-79.

103. Gilmartin ABH, Ural SH, Repke JT. Gestational diabetes mellitus. Rev Obstet Gynecol. 2008;1:129-34.

104. Benaiges D, Flores-Le Roux JA, Marcelo I, Mañé L, Rodríguez M, Navarro X, Chillarón JJ, Llauradó G, Gortazar L, Pedro-Botet J, Payà A. Is first-trimester $\mathrm{HbA} 1 \mathrm{c}$ useful in the diagnosis of gestational diabetes? Diabetes Res Clin Pract. 2017;133:85-91.

105. Committee on Practice Bulletins-Obstetrics. ACOG practice bulletin no 190: gestational diabetes mellitus. Obstet Gynecol. 2018;131:e49-64.

106. American Diabetes Association. Diagnosis and classification of diabetes mellitus. Diabetes Care. 2011;34(Suppl 1):S62-9.

107. Hod M, Kapur A, Sacks DA, Hadar E, Agarwal M, Di Renzo GC, et al. The International Federation of Gynecology and Obstetrics (FIGO) Initiative on gestational diabetes mellitus: a pragmatic guide for diagnosis, management, and care. Int J Gynaecol Obstet. 2015;131(Suppl 3):S173-211.

108. Dungan KM. 1,5-anhydroglucitol (GlycoMark) as a marker of short-term glycemic control and glycemic excursions. Expert Rev Mol Diagn. 2008;8:9-19.

109. Corcoran SM, Achamallah N, Loughlin JO, Stafford P, Dicker P, Malone $F D$, Breathnach F. First trimester serum biomarkers to predict gestational diabetes in a high-risk cohort: striving for clinically useful thresholds. Eur J Obstet Gynecol Reprod Biol. 2018;1 (222):7-12.

110. Katsiki N, Mikhailidis DP, Banach M. Leptin, cardiovascular diseases and type 2 diabetes mellitus. Acta Pharmacol Sin. 2018;39:1176-88.

111. López-Tinoco C, Roca M, Fernández-Deudero A, García-Valero A, Bugatto F, Aguilar-Diosdado M, et al. Cytokine profile, metabolic syndrome and cardiovascular disease risk in women with late-onset gestational diabetes mellitus. Cytokine. 2012;58:14-9.

112. Gao X, Yang H, Zhao Y. Variations of tumor necrosis factor-alpha, leptin and adiponectin in mid-trimester of gestational diabetes mellitus. Chin Med J. 2008;121:701-5.

113. Boyadzhieva M, Atanasova I, Zacharieva S, Kedikova S. Adipocytokines during pregnancy and postpartum in women with gestational diabetes and healthy controls. J Endocrinol Invest. 2013;36:944-9.

114. Bozkurt L, Göbl CS, Baumgartner-Parzer S, Luger A, Pacini G, KautzkyWiller A. Adiponectin and leptin at early pregnancy: association to actual glucose disposal and risk for GDM-A prospective cohort study. Int J Endocrinol. 2018;2018:5463762.

115. Yuan X-S, Shi H, Wang H-Y, Yu B, Jiang J. Ficolin-3/adiponectin ratio for the prediction of gestational diabetes mellitus in pregnant women. J Diabetes Investig. 2018;9:403-10.

116. Williams MA, Qiu C, Muy-Rivera M, Vadachkoria S, Song T, Luthy DA. Plasma adiponectin concentrations in early pregnancy and subsequent risk of gestational diabetes mellitus. J Clin Endocrinol Metab. 2004;89:2306-11. 
117. Cseh K, Baranyi E, Melczer Z, Kaszás E, Palik E, Winkler G. Plasma adiponectin and pregnancy-induced insulin resistance. Diabetes Care. 2004;27:274-5.

118. Thagaard IN, Krebs L, Holm J-C, Lange T, Larsen T, Christiansen M. Adiponectin and leptin as first trimester markers for gestational diabetes mellitus: a cohort study. Clin Chem Lab Med. 2017;55:1805-12.

119. Abell SK, Shorakae S, Harrison CL, Hiam D, Moreno-Asso A, Stepto NK, et al. The association between dysregulated adipocytokines in early pregnancy and development of gestational diabetes. Diabetes Metab Res Rev. 2017;33(8):e2926.

120. Maged AM, Moety GAF, Mostafa WA, Hamed DA. Comparative study between different biomarkers for early prediction of gestational diabetes mellitus. J Matern Fetal Neonatal Med. 2014;27:1108-12.

121. Kansu-Celik H, Ozgu-Erdinc AS, Kisa B, Findik RB, Yilmaz C, Tasci Y. Prediction of gestational diabetes mellitus in the first trimester: comparison of maternal fetuin-A, $\mathrm{N}$-terminal proatrial natriuretic peptide, high-sensitivity C-reactive protein, and fasting glucose levels. Arch Endocrinol Metab. 2019;63:121-7.

122. Salmi AA, Zaki NMN, Zakaria R, Nor Aliza AG, Rasool AH. Arterial stiffness, inflammatory and pro-atherogenic markers in gestational diabetes mellitus. VASA. 2012;41:96-104.

123. Mehmood S, Ye C, Connelly PW, Hanley AJ, Zinman B, Retnakaran R. Rising plasminogen activator inhibitor-1 and hypoadiponectinemia characterize the cardiometabolic biomarker profile of women with recent gestational diabetes. Cardiovasc Diabetol. 2018;17:133.

124. Chang Y-H, Chang D-M, Lin K-C, Shin S-J, Lee Y-J. Visfatin in overweight/obesity, type 2 diabetes mellitus, insulin resistance, metabolic syndrome and cardiovascular diseases: a meta-analysis and systemic review. Diabetes Metab Res Rev. 2011;27:515-27.

125. Ferreira AFA, Rezende JC, Vaikousi E, Akolekar R, Nicolaides KH. Maternal serum visfatin at 11-13 weeks of gestation in gestational diabetes mellitus. Clin Chem. 2011;57:609-13.

126. Rezvan N, Hosseinzadeh-Attar MJ, Masoudkabir F, Moini A, Janani $L$, Mazaherioun M. Serum visfatin concentrations in gestational diabetes mellitus and normal pregnancy. Arch Gynecol Obstet. 2012;285:1257-62.

127. Kaygusuz I, Gumus II, Yılmaz S, Simavlı S, Uysal S, Derbent AU, et al. Serum levels of visfatin and possible interaction with iron parameters in gestational diabetes mellitus. Gynecol Obstet Invest. 2013:75:203-9.

128. Cortelazzi D, Corbetta S, Ronzoni S, Pelle F, Marconi A, Cozzi V, Cetin I, Cortelazzi R, Beck-Peccoz P, Spada A. Maternal and foetal resistin and adiponectin concentrations in normal and complicated pregnancies. Clin Endocrinol (Oxf). 2007;66(3):447-53.

129. Megia A, Vendrell J, Gutierrez C, Sabaté M, Broch M, Fernández-Real $\mathrm{J}-\mathrm{M}$, et al. Insulin sensitivity and resistin levels in gestational diabetes mellitus and after parturition. Eur J Endocrinol. 2008;158:173-8.

130. Yang RZ, Lee MJ, Hu H, Pray J, Wu HB, Hansen BC, Shuldiner AR, Fried SK, McLenithan JC, Gong DW. Identification of omentin as a novel depot-specific adipokine in human adipose tissue: possible role in modulating insulin action. Am J Physiol Endocrinol Metab. 2006;290(6):E12.

131. Wu LE, Samocha-Bonet D, Whitworth PT, Fazakerley DJ, Turner N, Biden TJ, et al. Identification of fatty acid binding protein 4 as an adipokine that regulates insulin secretion during obesity. Mol Metab. 2014;3:465-73.

132. Zabetian-Targhi F, Mahmoudi MJ, Rezaei N, Mahmoudi M. Retinol binding protein 4 in relation to diet, inflammation, immunity, and cardiovascular diseases. Adv Nutr. 2015;6:748-62.

133. Tu WJ, Guo M, Shi XD, Cai Y, Liu Q, Fu CW. First-trimester serum fatty acid-binding protein 4 and subsequent gestational diabetes mellitus. Obstet Gynecol. 2017;130(5):1011-6.

134. Li YY, Xiao R, Li CP, Huangfu J, Mao JF. Increased plasma levels of FABP4 and PTEN is associated with more severe insulin resistance in women with gestational diabetes mellitus. Med Sci Monit. 2015;8(21):426-31.

135. Ning $H$, Tao $H$, Weng $Z$, Zhao X. Plasma fatty acid-binding protein 4 (FABP4) as a novel biomarker to predict gestational diabetes mellitus. Acta Diabetol. 2016;53:891-8.

136. Du C, Kong F. A prospective study of maternal plasma concentrations of retinol-binding protein 4 and risk of gestational diabetes mellitus. Ann Nutr Metab. 2019;74:1-8.
137. Mirza MA, Hansen T, Johansson L, Ahlström H, Larsson A, TE Lind LL. Relationship between circulating FGF23 and total body atherosclerosis in the community. Nephrol Dial Transplant. 2009;24(10):3125-31.

138. Mirza MA, Larsson A, Melhus H, Lind L, Larsson TE. Serum intact FGF23 associate with left ventricular mass, hypertrophy and geometry in an elderly population. Atherosclerosis. 2009;207:546-51.

139. Tuñón J, Fernández-Fernández B, Carda R, Pello AM, Cristóbal C, Tarín N, Aceña Á, González-Casaus ML, Huelmos A, Alonso J, Lorenzo Ó, González-Parra E, Hernández-González I, Mahílo-Fernández I, LópezBescós LEJ. Circulating fibroblast growth factor-23 plasma levels predict adverse cardiovascular outcomes in patients with diabetes mellitus with coronary artery disease. Diabetes Metab Res Rev. 2016:32(7):685-93.

140. Kizilgul M, Kan S, Beysel S, Apaydin M, Ozcelik O, Caliskan M, et al. Is fibroblast growth factor 23 a new cardiovascular risk marker in gestational diabetes? Arch Endocrinol Metab. 2017;61:1-5.

141. Kirwan JP, Hauguel-De Mouzon S, Lepercq J, Challier J-C, Huston-Presley $L$, Friedman JE, et al. TNF-alpha is a predictor of insulin resistance in human pregnancy. Diabetes. 2002;51:2207-13.

142. Harlev A, Wiznitzer A. New insights on glucose pathophysiology in gestational diabetes and insulin resistance. Curr Diabetes Rep. 2010;10:242-7.

143. Ding EL, Song Y, Malik VS, Liu S. Sex Differences of endogenous sex hormones and risk of type 2 diabetes: a systematic review and metaanalysis. JAMA. 2006;295(11):12.

144. Smirnakis KV, Plati A, Wolf M, Thadhani R, Ecker JL. Predicting gestational diabetes: choosing the optimal early serum marker. Am J Obstet Gynecol. 2007;196:410.e1-6 (discussion 410.e6-7).

145. Zhang T, Du T, Li W, Yang S, Liang W. Sex hormone-binding globulin levels during the first trimester may predict gestational diabetes mellitus development. Biomark Med. 2018;12(3):239.

146. Nanda S, Savvidou M, Syngelaki A, Akolekar R, Nicolaides KH. Prediction of gestational diabetes mellitus by maternal factors and biomarkers at 11 to 13 weeks. Prenat Diagn. 2011;31(2):135-41.

147. Kralisch S, Hoffmann A, Lössner U, Kratzsch J, Blüher M, Stumvoll M, et al. Regulation of the novel adipokines/hepatokines fetuin A and fetuin B in gestational diabetes mellitus. Metab Clin Exp. 2017;68:88-94.

148. Bonakdaran S, Khorasani ZM, Jafarzadeh F. Increased serum level of FGF21 in gestational diabetes mellitus. Acta Endocrinol (Buchar). 2017;13:278-81.

149. Köninger A, Mathan A, Mach P, Frank M, Schmidt B, Schleussner E, et al. Is afamin a novel biomarker for gestational diabetes mellitus? A pilot study. Reprod Biol Endocrinol. 2018;16:30.

150. Näf S, Escote X, Ballesteros M, Yañez RE, Simón-Muela I, Gil P, Albaiges G, Vendrell J, Megia A. Serum activin A and follistatin levels in gestational diabetes and the association of the activin a-follistatin system with anthropometric parameters in offspring. PLoS ONE. 2014;9(4):e92175.

151. De Rosa S, Arcidiacono B, Chiefari E, Brunetti A, Indolfi C, Foti DP. Type 2 diabetes mellitus and cardiovascular disease: genetic and epigenetic links. Front Endocrinol (Lausanne). 2018;9:2.

152. Poirier C, Desgagné $V$, Guérin R, Bouchard L. MicroRNAs in pregnancy and gestational diabetes mellitus: emerging role in maternal metabolic regulation. Curr Diabetes Rep. 2017;17:35.

153. Morales-Prieto DM, Ospina-Prieto S, Schmidt A, Chaiwangyen W, Markert UR. Elsevier trophoblast research award lecture: origin, evolution and future of placenta miRNAs. Placenta. 2014;35(Suppl):S39-45.

154. Zhao C, Dong J, Jiang T, Shi Z, Yu B, Zhu Y, Chen D, Xu J, Huo R, Dai J, Xia Y, Pan S, Hu ZSJ. Early second-trimester serum miRNA profiling predicts gestational diabetes mellitus. PLOS ONE. 2011;6(8):e2392.

155. He A, Zhu L, Gupta N, Chang Y, Fang F. Overexpression of micro ribonucleic acid 29 , highly up-regulated in diabetic rats, leads to insulin resistance in 3T3-L1 adipocytes. Mol Endocrinol. 2007;21:2785-94.

156. Shang J, Li J, Keller MP, Hohmeier HE, Wang Y, Feng Y, Zhou HH, Shen X, Rabaglia M, Soni M, Attie AD. Induction of miR-132 and miR-212 expression by glucagon-like peptide 1 (GLP-1) in rodent and human pancreatic $\beta$-cells. Mol Endocrinol. 2015;29(9):1243-53.

157. Shi Z, Zhao C, Guo X, Ding H, Cui Y, Shen R, et al. Differential expression of microRNAs in omental adipose tissue from gestational diabetes mellitus subjects reveals miR-222 as a regulator of ERa expression in estrogen-induced insulin resistance. Endocrinology. 2014;155:1982-90. 
158. Zhu Y, Tian F, Li H, Zhou Y, Lu J, Ge Q. Profiling maternal plasma microRNA expression in early pregnancy to predict gestational diabetes mellitus. Int J Gynaecol Obstet. 2015;130:49-53.

159. Cao Y-L, Jia Y-J, Xing B-H, Shi D-D, Dong X-J. Plasma microRNA-16-5p, -17-5p and -20a-5p: novel diagnostic biomarkers for gestational diabetes mellitus. J Obstet Gynaecol Res. 2017:43:974-81.

160. Fernandes T, Magalhães FC, Roque FR, Phillips MI, Oliveira EM. Exercise training prevents the microvascular rarefaction in hypertension balancing angiogenic and apoptotic factors: role of microRNAs-16,-21, and -126. Hypertension. 2012;59:513-20.

161. Sen CK, Gordillo GM, Khanna S, Roy S. Micromanaging vascular biology: tiny microRNAs play big band. J Vasc Res. 2009;46:527-40.

162. Zhang $X$, Chen Y, Zhao P, Zang L, Zhang Z, Wang X. MicroRNA-19a functions as an oncogene by regulating PTEN/AKT/PAKT pathway in myeloma. Leuk Lymphoma. 2017;58:932-40.

163. Wang D, Wang Y, Ma J, Wang W, Sun B, Zheng T, et al. MicroRNA-20a participates in the aerobic exercise-based prevention of coronary artery disease by targeting PTEN. Biomed Pharmacother. 2017;95:756-63.

164. Wander PL, Boyko EJ, Hevner K, Parikh VJ, Tadesse MG, Sorensen TK, et al. Circulating early- and mid-pregnancy microRNAs and risk of gestational diabetes. Diabetes Res Clin Pract. 2017;132:1-9.

165. Hocaoglu M, Demirer S, Senturk H, Turgut A, Komurcu-Bayrak E. Differential expression of candidate circulating microRNAs in maternal blood leukocytes of the patients with preeclampsia and gestational diabetes mellitus. Pregnancy Hypertens. 2019;17:5-11.

166. Deiuliis JA. MicroRNAs as regulators of metabolic disease: pathophysiologic significance and emerging role as biomarkers and therapeutics. Int J Obes (Lond). 2016;40:88-101.
167. Ling H-Y, Hu B, Hu X-B, Zhong J, Feng S-D, Qin L, et al. MiRNA-21 reverses high glucose and high insulin induced insulin resistance in 3T3-L1 adipocytes through targeting phosphatase and tensin homologue. Exp Clin Endocrinol Diabetes. 2012;120:553-9.

168. López-Hernández Y, Herrera-Van Oostdam AS, Toro-Ortiz JC, López JA Salgado-Bustamante M, Murgu M, et al. Urinary metabolites altered during the third trimester in pregnancies complicated by gestational diabetes mellitus: relationship with potential upcoming metabolic disorders. Int J Mol Sci. 2019:20:1186.

169. Xu C, Han Z, Li P, Li X. Fibroblast growth factor-21 is a potential diagnostic factor for patients with gestational diabetes mellitus. Exp Ther Med. 2018;16(2):1397-402

170. Park S, Kim M-Y, Baik SH, Woo J-T, Kwon YJ, Daily JW, et al. Gestational diabetes is associated with high energy and saturated fat intakes and with low plasma visfatin and adiponectin levels independent of prepregnancy BMI. Eur J Clin Nutr. 2013;67:196-201.

171. Morisset A-S, Dubé M-C, Côté JA, Robitaille J, Weisnagel SJ, Tchernof A. Circulating interleukin- 6 concentrations during and after gestational diabetes mellitus. Acta Obstet Gynecol Scand. 2011;90:524-30.

\section{Publisher's Note}

Springer Nature remains neutral with regard to jurisdictional claims in published maps and institutional affiliations.
Ready to submit your research? Choose BMC and benefit from:

- fast, convenient online submission

- thorough peer review by experienced researchers in your field

- rapid publication on acceptance

- support for research data, including large and complex data types

- gold Open Access which fosters wider collaboration and increased citations

- maximum visibility for your research: over 100M website views per year

At BMC, research is always in progress.

Learn more biomedcentral.com/submissions 